\title{
Mass Refugee Influxes, Refoulement \\ and the \\ and the
Prohibition Against Torture
}

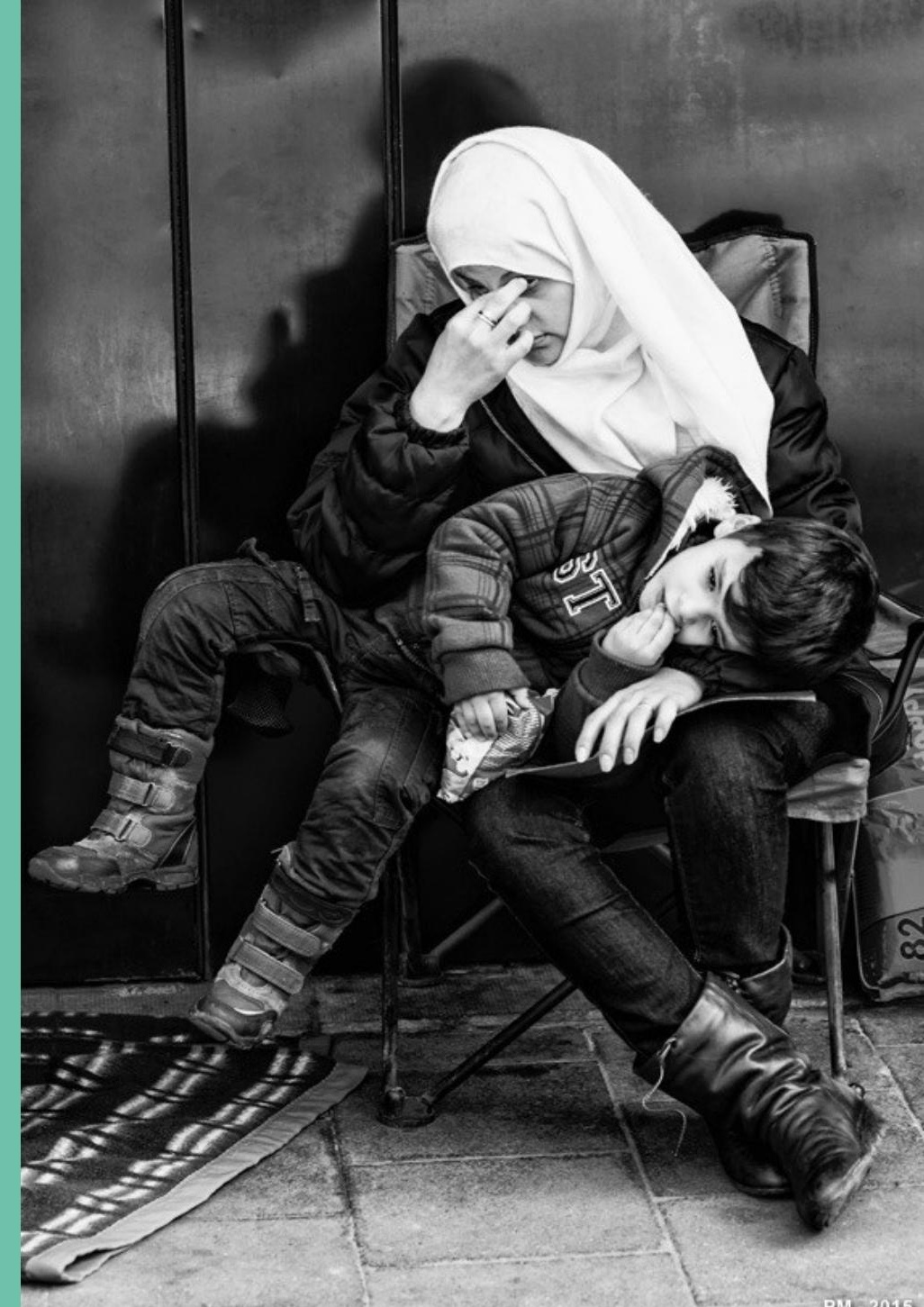




\section{Photo credits:}

\section{Front cover:}

Refugees, Fusan, Korea December 1945, Don O’Brien [Flickr; https://www.flickr.com/photos/dok1/]

Pietà, Syrian refugees - Brussels, Patrick Marioné [Flickr,

https://www.flickr.com/photos/p marione/21857761066/in/album-72157642255991444/]

The kids in the refugee camp, Bjørn Heidenstrøm, 28 June 2010, [Flickr, www.flickr.com/photos/heidenstrom]

\section{Back cover:}

Refugees, Fusan, Korea December 1945, Don O’Brien [Flickr; https://www.flickr.com/photos/dok1/]

The kids in the refugee camp, Bjørn Heidenstrøm, 28 June 2010, [Flickr, www.flickr.com/photos/heidenstrom] 


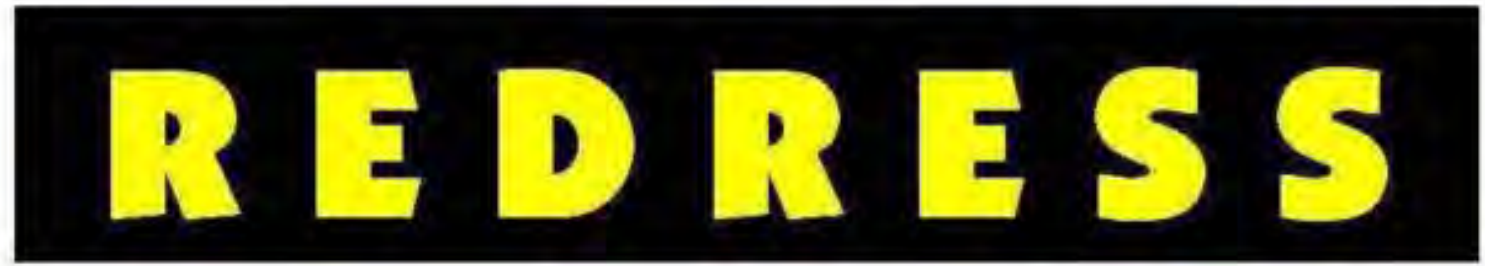

\section{Ending Torture. Seeking Justice for Survivors}

\section{Mass Refugee Influxes, Refoulement and the Prohibition Against Torture}

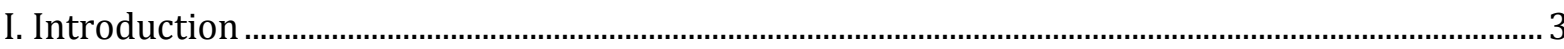

II. The Securitisation of Refugee Protection .......................................................................................... 6

II.1 The Securitisation of Language and the Creation of Mythologies ................................................ 6

II.2 Law, Exceptionalism and National Security............................................................................. 9

II.2.1 Exclusions and National Security Paradigms ...................................................................... 9

II.2.2 Recognised refugees - exceptions to the obligation to avoid expulsions and

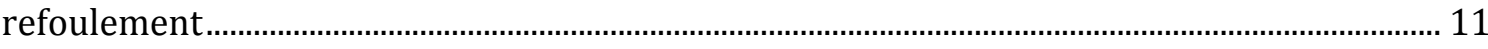

II.2.3 The absolute prohibition of torture as a form of added protection ................................... 12

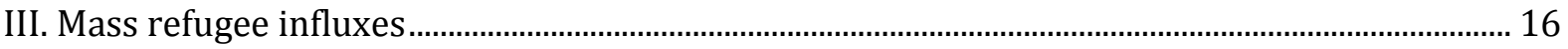

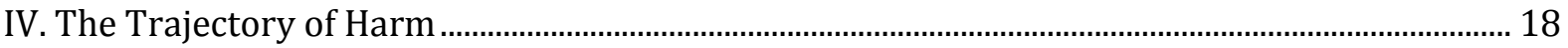

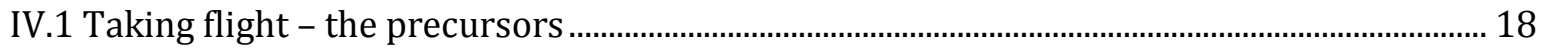

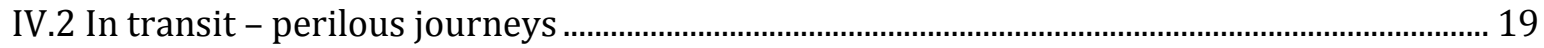

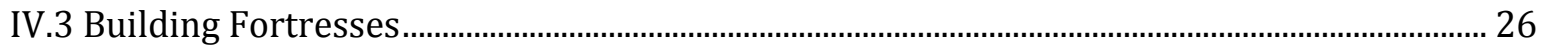

IV.3.1 Closing borders and building physical barriers .................................................................. 28

IV.3.2 'Pushbacks', interdiction on the High Seas and off-shore processing arrangements. 29

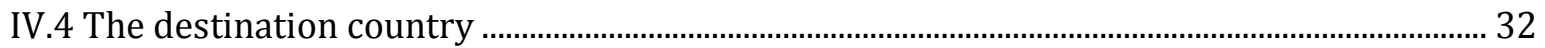

IV.4.1 Refugee claims determination ................................................................................................... 33

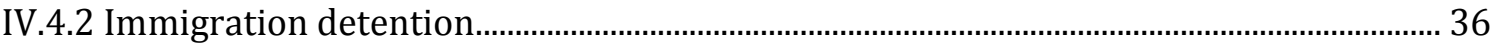

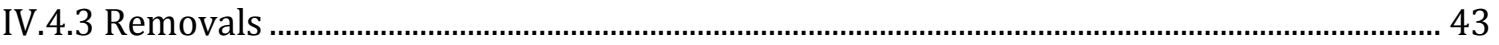

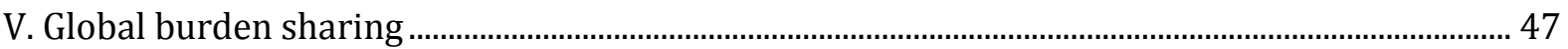

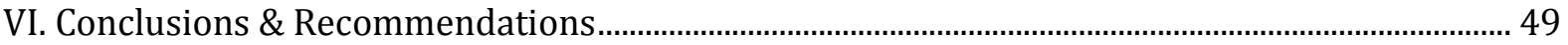




\section{Introduction}

An epic number of refugees and migrants are leaving their countries. The UN High Commissioner for Refugees has reported 'the highest levels of displacement on record,' with an unprecedented 65.3 million people around the world forced from home. ${ }^{1}$ Millions upon millions of these persons - the vast majority, have become displaced internally or have migrated or sought refuge in neighbouring countries, particularly in Africa and the Middle East. A significant and growing number of others have embarked on dangerous and complex journeys to reach other regions, particularly in Europe, North America and Australia. The movement of people is not a new or novel phenomenon; it is a normal response to the will to survive and to prosper, fuelled by devastating conflicts, political repression, weak governance, mass human rights abuses, economic disenfranchisement, environmental degradation and growing global inequality in many parts of the world.

Regardless of the reason for their journeys, the individuals and families who manage to leave their countries of origin are often exhausted, traumatised and in need of humanitarian and medical assistance, especially the most vulnerable among them.

A vast proportion of refugees and other migrants experience cruel, inhuman or degrading treatment, at times amounting to torture, at all stages of their journey.

A triple syndrome of harm characterises many of their situations:

i) The harm suffered in their home country which was the precursor or one of the causes of their departure;

ii) The harm suffered during their arduous journeys to 'safety', often passing through multiple countries and being subjected to the whims of non-state actors such as smugglers, militia and criminal gangs or corrupt governments. Sometimes destination countries have made arrangements with transit countries to detain or otherwise prevent individuals from reaching their destination; these arrangements have regularly resulted in inhuman conditions and torture, often reaching crisis proportions;

iii) The harrowing experiences in the destination country - typically characterised by poverty, uncertainty, alienation and discrimination. For the most vulnerable individuals fleeing their countries of origin, the mere fact of detention, and the way asylum claims are processed and the lack of adequate facilities and basic necessities may amount to ill-treatment in its own right. Indefinite detention, poor conditions of detention, and various forms of ill-treatment - by guards or fellow inmates or during removals, including various forms of sexual and other gender-based violence - are a lived reality for many.

This triple syndrome of harm exacerbates vulnerability yet it is rarely acknowledged and even more rarely taken into account by the many border guards and other officials who come into contact with these marginalised persons. To the contrary, a combination of abdication of responsibility and a positive attempt to make reception conditions difficult so as to discourage further movements of people accounts for and exacerbates much of the harm suffered.

${ }^{1}$ UNHCR website, http://www.unhcr.org/figures-at-a-glance.html 
Even though the main challenge facing those in protection is the absence of channels for safe and legal access to protection, receiving States have addressed the crisis by increasing border surveillance and reinforcing migration controls, rather than by providing a comprehensive humanitarian response. For the most part, receiving states have responded to the increase in the number of asylum applicants, and migrants more broadly, not with compassion and respect for individuals' dignity and humanity, but by pursuing technocratic policies of deterrence. The measures taken include visa restrictions and carrier sanctions; pushing back people trying to enter the territory by land or by sea by building perimeter fences and shutting border crossings; financing third states to detain individuals in transit countries and to patrol their borders so that they cannot continue their journeys. All these measures are aimed at preventing refugees and other migrants from reaching their destination: controlling or managing migration flows (managing numbers) or maintaining internal security (managing safety and security threats), instead of focusing on the rights of individuals and corresponding obligations of states under national and international law.

The deterrence policies are effectuated by broad executive powers; privatisation of many aspects of the reception, claims determination, detention and removal processes; limited transparency, safeguards and accountability and the lack of effective remedies and reparation. The dehumanisation of refugees and other migrants also creates an environment in which allegations of ill-treatment based on sexual and/or racial discrimination are rife, though little is done in response.

These policies of deterrence are inappropriate and problematic, particularly given their incompatibility in practice with states' obligations under the 1951 Refugee Convention. Given the very foreseeable and grave humanitarian consequences to those policies - including widespread, preventable deaths in the Mediterranean Sea and countless refoulements to countries where persons face significant risks of persecution, including torture and death, there is a need to assess the wider legal consequences of deterrence policies. A laissez-faire approach to human suffering when states have a duty to act, engages states' legal responsibility, in addition to their obvious moral responsibilities.

This Report is released by REDRESS on the eve of a summit of world leaders meeting at the United Nations General Assembly in New York, on 19 September 2016. They are coming together to discuss how to address these challenges, and are set to agree a Global Compact on responsibility-sharing relating to refugees. The Summit will be followed by a Leaders' Summit on refugees, hosted by USA President Obama, and focussed on humanitarian funding, resettlement quotas, and access to education and employment. These meetings present a crucial opportunity to address one of the worst humanitarian crises of our century and to confront a virtually broken system of refugee protection. Will the meetings and their follow-up processes go far enough? Will racism, xenophobia, and fortress mentalities give way to a new era of humanitarianism and collective resolve? The International Community cannot fail; there is too much at stake.

This Report analyses these problems through the lens of the incontrovertible obligation of states to prevent and respond to torture, and to support the victims of this atrocious crime. Our analysis is with a view to (i) identifying the nature and scale of torture and ill-treatment experienced by asylum seekers and other migrants at all stages of their "journey"; (ii) examining the compatibility of laws and practices with states' obligations; and (iii) highlighting how underlying policies and structural factors create regimes that heighten the risks that those seeking entry will be subjected to torture and related abuse.

The Report draws on a range of sources, focusing particularly on several countries that receive numerous asylum applications. It also analyses the role played by transit countries and offshore processing centres, both in serving the ends of the destination countries, but also in 
fostering themselves, environments in which individuals regularly face torture and other prohibited ill-treatment. These are by no means the only countries whose policies, laws and practices raise concerns. However, their approaches, in addition to being problematic in view of the extent of the allegations of ill-treatment, have been appropriated by other countries facing similar migration challenges.

On the basis of findings made, the Report calls on Summit Leaders, states and relevant international and regional organisations, to be bold and to be brave and to demonstrate the collective leadership and humanity that is clearly required to address this crisis. The status quo is not working. Policies, laws and practices must be revised at all levels to strengthen all individuals' rights not to be tortured.

We hope that the Report will provide a useful resource and tool for analysis, advocacy and reforms for those seeking to secure the rights of persons who are frequently made to suffer, often repeatedly, simply for the fact of 'being at the wrong place at the wrong time'.

The report was written by Carla Ferstman and Lutz Oette. REDRESS expresses its appreciation to the SOAS, University of London, Human Rights Clinic, and in particular its convenor, Professor Lynn Welchman and Aditi Jaganathan, Chiara Petrucci, Claudia Tomarchio, Gemma Daly, as well as Emily Hindle for their invaluable research assistance. 


\section{The Securitisation of Refugee Protection}

\section{II.1 The Securitisation of Language and the Creation of Mythologies}

Language has been a key arsenal in the securitisation of refugee protection and migration control, and entrenches policy. Language has been used to stir up fear in many destination countries about the impact of receiving large numbers of refugees and other migrants. Fear has tended to be mobilised through the use of a combination of discriminatory and xenophobic stereotypes:

i) The unknown 'alien' - focussing on difference; different religion, culture, traditions which will infect or negatively impact on the traditions of the host state. Linked to this is the wish to dehumanise, the stoking of fears that the unknown 'alien' will not be capable of or interested in respecting the values of the host state - whether these are religious or personal values and beliefs. There is often a fear that accepting large numbers of persons from a different faith or culture will upset the natural majority/minority balance in the host state, and potentially destabilise that state. In one notorious and extreme example, a Polish magazine published on its front cover a depiction of a white woman being accosted and grabbed by three dark-skinned hands, with the headline "The Islamic rape of Europe.'2

To dehumanise a person or group of persons can be understood as denying their individuality and humanity, and excluding them from the moral community to which generally agreed notions such as values and fairness apply. ${ }^{3}$ As a result, the person or group of persons concerned becomes stigmatised and is seen as inferior and less deserving of respect for his or her dignity and rights. The treatment of Jews and other 'undesirable' people in Nazi Germany who were stripped of their citizenship and other rights, subjected to a range of measures designed to signal their supposed inferiority, and depicted as dangerous and dirty animals in Nazi propaganda is the starkest example of dehumanising a whole people. Migrants and asylum seekers are frequently stripped of their individuality and referred to in terms that have derogatory connotations, often taken from animal and natural life, such as a 'swarm', 'flood', 'invasion' or 'epidemic'. In the Australian context, a study found that the

... asylum seekers have primarily been represented as medium or large groups and through a focus on boats. We argue that this visual framing, and in particular the relative absence of images that depict individual asylum seekers with recognisable facial features, associates refugees not with a humanitarian challenge, but with threats to sovereignty and security. These dehumanising visual patterns reinforce a politics of fear that explains why refugees are publicly framed as people whose plight, dire as it is, nevertheless does not generate a compassionate political response. ${ }^{4}$

\footnotetext{
${ }^{2}$ Harriet Sherwood, 'Polish magazine's "Islamic rape of Europe" cover sparks outrage', The Guardian, 18 February 2016

${ }^{3}$ Nick Haslam, 'Dehumanization: An Integrative Review', 10(3) (2006) Personality and Social Psychology Review 252

${ }^{4}$ Roland Bleiker et al., 'The Visual Dehumanisation of Refugees', (2013) 48(4) Australian Journal of Political Science, 398-416
} 
ii) Economics - the usurping 'alien' coming to take our jobs; causing a drain on public services including housing, health care and schooling. ${ }^{5}$

\section{Asylum-seeking and Criminality}

'We know irregular migration isn't a crime - not against persons, not against property, not against the security of the state. It is a violation of an administrative regulation that obliges us to present ourselves at a specific point of entry with appropriate papers. But a crime it is not. Refugees and migrants who cross borders irregularly do not have the feeling of committing a crime, even if they know that what they are doing is not authorised. We don't have the moral high ground here: migrants are mostly courageous people who have endured a lot, are resilient, and want to do the right thing for themselves and their family.' 6

Even though the act of seeking asylum is a perfectly legal matter, language has been used to label migrants as 'irregular' or 'illegal' translating individuals' desperate search for refuge into a quasi-criminal act. ${ }^{7}$ As highlighted by the Special Rapporteur on the Human Rights of Migrants in the EU context:

"The view of migrants among many stakeholders as "illegal" is counterproductive and is not based on facts or the provisions of international law. While migrants who come to the European Union without documents are in an irregular situation (or "undocumented" or "unauthorized"), they have not committed a criminal act. The conceptualization of irregular migrants as "illegal" has undoubtedly played into the use of immigration detention. It has also had an impact on the general public's perception of migrants, legitimizing policies that are not in line with human rights guarantees and contributing to xenophobia and discrimination.'8

As legal immigration has in most countries become increasingly difficult for nonprivileged persons due to restrictive policies, migrants, even where they do not fall within the definition of refugee under international law, are often faced with a choice of entering and remaining in a country illegally or applying for asylum - the notion of the 'bogus refugee'. This development risks that the notion of "refugee" and the system of refugee protection is questioned, where it is equated with attempts to bypass immigration rules; these individuals are positioned as rule-breakers, untrustworthy, criminal.

Host states are responsible for closing their borders, which is a direct cause of bourgeoning smugglers and trafficking networks; ' criminalisation drives all irregular migrants further underground, into the hands of smugglers and exploitative employers and landlords. If the host states' objective is effectively to control borders, such criminalisation is counterproductive, since it entrenches mobile, creative, and techsavvy smuggling rings that take over the control of cross-border movements of

\footnotetext{
${ }^{5}$ Patson Muzuwa, a torture survivor and refugee from Zimbabwe explains: 'I am deeply embarrassed when I meet people who think asylum seekers like me are just people who need some money. I'm not here to study, I'm not here to make a fortune , I'm not in this country to steal any benefits from anyone, I pay my own taxes. I want to be seen as a refugee and not as a thief.' REDRESS, Torture: Stories of Survival, June 2005, 31

${ }^{6}$ François Crépeau, 'Rejecting Criminalisation and Externalisation: Moving from Enforced Closure to Regulated Mobility' (2015) 104 Geo LJ Online 115, 120

${ }^{7}$ Catherine Dauvergne, Making People Illegal: What Globalization means for Migration and Law (Cambridge: Cambridge University Press, 2008)

${ }^{8}$ François Crépeau , 'Banking on mobility over a generation: follow-up to the regional study on the management of the external borders of the European Union and its impact on the human rights of migrants', Report of the Special Rapporteur on the human rights of migrants, François Crépeau, UN Doc A/HRC/29/36, 8 May 2015, para. 72
} 
persons. ${ }^{9}$ At the same time, states' focus on the criminalisation of smugglers - is appropriate yet it is also part of the politics of deflecting blame away from the governments who have failed to establish safe routes through which individuals seeking protection can have their claims assessed. Furthermore, economic migration is not a sin or a crime - it is a necessary bi-product of global fiscal policies and interconnected economies. The desire/need to seek out opportunities is natural and must be seen in its historical context over many generations.

The systematic policies to detain irregular migrants and refugees are also a form of criminalisation. As Crépeau has explained, 'administrative detention has increased exponentially, without effective oversight mechanisms that could address the issues relating to the criteria for, duration of, and conditions of detention. The idea of detention as a last resort, only if absolutely necessary, is applied almost nowhere, and alternatives to detention haven't been seriously developed in any country I've visited.'10

iv) The influx of persons will increase the pressure on policing and security making it difficult to deter undesirable or dangerous persons heightening the prospects of terrorism. Instead of emphasising the legal and moral imperative to protect vulnerable persons, the paradigm shifts to the need to protect national security interests above any other interests. For instance, this underpins Australia's approach. In response to the number of asylum seekers, mainly from Afghanistan, Iran, Iraq and Sri Lanka, seeking to reach its territory by boat, Australia introduced a policy known as "Pacific Solution"11 in 2001. This controversial policy was ended in 2007 but effectively revived in September 2013 with the introduction of "Operation Sovereign Borders." This 2013 policy treats asylum seekers and other migrants as a threat to Australia's national security. Operation Sovereign Borders is a military-led operation. Similarly, NATO warships have been used in the Aegean Sea to stop the flow of refugees to Europe in an operation designed to counter human trafficking and criminal networks, but undoubtedly also having the effect of preventing refugees from reaching safety in Europe.

The scale of current migration levels have been termed 'unprecedented', a 'crisis'. Emphasising the tremendous scale of the issue tends to be a precursor for governments and other policy makers to explain why exceptions are needed; why the law as it stands cannot and should not be applied. The claim is often made that a mass influx of refugees will threaten the security (even the very survival) of the state. States have diverged from their obligations not to refoule refugees when they consider it necessary or in their interest to do so, often explaining their actions in terms of the exceptional circumstances.

These fears have not only helped to underpin many governments' policies of deterrence; they have also sparked racism and xenophobia which is already having a deleterious impact on community cohesion and with major boosts to both the nationalistic and exceptionalist internal and foreign policies of many countries, far beyond the areas of asylum and migration.

Dehumanisation, whether intended or resulting from the portrayal of migrants and asylum seekers, also increases individuals' vulnerability to hate crimes in the destination country, such as attacks on shelters housing asylum seekers, beatings and attacks of visible minorities and inflammatory graffiti. It also creates an environment in which the potential for torture and other

\footnotetext{
${ }^{9}$ François Crépeau, 'Rejecting Criminalisation and Externalisation: Moving from Enforced Closure to Regulated Mobility' (2015) 104 Geo LJ Online 115, 117

${ }^{10}$ Ibid, 116-7

${ }^{11}$ See further Janet Philip, The 'Pacific Solution' revisited: a statistical guide to the asylum seeker caseloads on Nauru and Manus Island, Parliament of Australia, 4 September 2012,

http://parlinfo.aph.gov.au/parlInfo/download/library/prspub/1893669/upload binary/1893669.pdf;fileType=application\%2Fpdf
} 
forms of ill-treatment by public officials is increased. By seeing these persons as a threat or as undeserving and unwelcome, dehumanisation lowers the threshold for ill-treatment for those exercising power over migrants and asylum seekers. At the same time, migrants and asylum seekers often have a precarious legal status, are in a vulnerable situation and may not be in a position to effectively respond to threats or intimidation, which limits the likelihood that they will take action against abuse. This serves to silence them and is likely to result in, or perpetuate any impunity for torture. In addition, the fact that asylum seekers do not have rights of political participation frequently means that they will enjoy limited political support, which risks further weakening their position, including any calls to strengthen their rights and to provide better systems of protection.

Grassroots citizens' movements in receiving countries and certain refugee-friendly governments such as those in place in Canada and Germany have sought to counteract the tendencies towards dehumanisation. The adoption of the slogan 'Refugees are Welcome Here'12 has been an important rallying point but more than slogans are required to stem the tide of xenophobia and to improve respect for the rights of those concerned.

The underlying policies and sentiments in many countries remain hostile to admitting a substantial number of asylum seekers and/or other migrants.

\section{II.2 Law, Exceptionalism and National Security}

Refugee law is designed to ensure that persons with a well-founded fear of persecution can safely claim and obtain refuge. But national security considerations have become increasingly important rationales to justify limitations on the recognition of persons as refugees and to minimise the protections offered to recognised refugees. In this section we explore how certain facets of the legal framework have been manipulated and exclusion clauses interpreted in overly broad ways to bar entry and/or to deny protection or expulse persons who should otherwise be entitled to protection. We also explore how other rules (mass movements; temporary protection) have been impacted by national security paradigms to the detriment of those seeking protection.

The refugee law framework is an essentially humanitarian framework designed to afford protection to those in need. It was never designed to apply to serious criminals, terrorists or others who pose a significant risk to the host country. Exceptionalism has been built in to the refugee law framework in several ways:

\section{II.2.1 Exclusions and National Security Paradigms}

The Refugee Convention has a number of exclusion clauses which are designed to ensure that persons who violate the rights of others or commit serious crimes do not benefit from protection and cannot 'abuse the institution of asylum in order to avoid being held legally accountable for their acts.' ${ }^{13}$ The Convention denies international protection to persons who would otherwise qualify as refugees if they fall within certain parameters. Under Article 1(f) of the Convention, refugee status does not apply to any person with respect to whom there are serious reasons for considering that: (a) he has committed a crime against peace, a war crime, or a crime against humanity, as defined in the international instruments drawn up to make provision in respect of such crimes; (b) he has committed a serious non-political crime outside

\footnotetext{
12 See e.g., Emma Graham-Harrison and Lizzy Davis, 'Refugees are Welcome Here: UK marchers take to streets with message of support', Guardian, 12 September 2015

13 Guidelines on International Protection: Application of the Exclusion Clauses: Article $1 F$ of the 1951 Convention relating to the Status of Refugees, UN Doc HCR/GIP/03/05, 4 September 2003, 2
} 
the country of refuge prior to his admission to that country as a refugee; (c) he has been guilty of acts contrary to the purposes and principles of the United Nations. A similar provision is found in Article I(5) of the Convention Governing the Specific Aspects of Refugee Problems in Africa. ${ }^{14}$

The wording of Article $1 \mathrm{~F}$ makes clear that the exclusion clauses apply not only to persons who have been convicted of crimes coming within the three sub-clauses, but also to persons against whom 'there are serious reasons for considering' that they may have committed those offences. There is a legitimate concern to ensure that the international refugee system is not abused by persons who are not deserving of protection, and hence the inclusion in the clauses of persons who have not been convicted of any crime. At the same time, however, it is important that the exclusion clauses do not become a route for states to arbitrarily deny access to international protection. Bona fide asylum-seekers should not be victimised by unduly broad legislative or administrative measures, designed to deter entry.

The jurisprudence has been relatively clear that the exclusion clauses must be restrictively interpreted and cautiously applied and there must be some objective basis for the belief of the person's individual responsibility for the crime. ${ }^{15}$ In this same sense, UNHCR has underscored that individual determinations are necessary; it is not enough for instance, to 'rely on the designation as "terrorist" of a particular crime, person or group. Rather than focusing on the label, it is necessary to determine whether the acts in question constitute crimes within the scope of article $1 \mathrm{~F} ;{ }^{\prime 16}$

where there is sufficient proof that an asylum-seeker belongs to an extremist group involved in the commission of serious crimes, including those considered to be of a terrorist nature, the information available about this group may support a finding that anyone who voluntarily becomes, or remains, a member may be considered to have incurred individual responsibility for the crimes in question. In asylum procedures, this may give rise to a rebuttable presumption of individual liability in such cases, resulting in the burden of proof shifting to the asylum-seeker. The position of the individual in the organization concerned, including the voluntariness of his or her membership, as well as the fragmentation of certain groups would nevertheless be examined and taken into account in reaching a determination on exclusion. ${ }^{17}$

Despite these cautions, there is significant contingency in the application. The crime of terrorism, which can fall within the exclusion clauses, has no internationally accepted definition. In the aftermath of the terrorist attacks of 11 September 2001, many states introduced overly broad framings of the definition which can leave the Refugee Convention's exclusion clause open to abuse. The adoption in November 2002 of Security Council Resolution 1377, which obliged Member States to take a range of measures to counter terrorism, called upon states to ensure that asylum-seekers that have planned, facilitated or participated in the commission of terrorist acts are not granted refugee status and that refugee status is not abused by perpetrators, organisers or facilitators of terrorist acts. It also set out that acts of international terrorism are contrary to the purposes and principles of the UN Charter, putting terrorism squarely within exclusion (c), yet the absence of a definition makes this prone to abuse.

The Office of the UN High Commissioner for Refugees has indicated that

\footnotetext{
${ }^{14}$ Convention Governing the Specific Aspects of Refugee Problems in Africa, Organization of African Unity (OAU) (adopted 10 September 1969, entered into force 20 June 1974) 1001 UNTS 45

${ }^{15}$ See, e.g., Mugesera v. Canada (Minister of Citizenship and Immigration) [2005] 2 SCR 100, para 114; Al-Sirri v Secretary of State for the Home Department, DD v Secretary of State for the Home Department [2012] UKSC 54 para 75

${ }^{16}$ UNHCR, Addressing Security Concerns without Undermining Refugee Protection - UNHCR's perspective - Rev 2, 17 Dec 2015, para 23

17 Ibid, para 24
} 
In the international community's efforts to combat acts of terrorism it is important that unwarranted associations between terrorists and refugees/asylum-seekers are avoided. Moreover, definitions of terrorist crimes adopted on the international, regional and national level will need to be extremely precise to ensure that the "terrorist" label is not abused for political ends, for example to prohibit the legitimate activities of political opponents. Such definitions may influence the interpretation of the exclusion clauses and, if distorted for political ends, could lead to the improper exclusion of certain individuals. Indeed, unwarranted applications of the "terrorist" label could trigger recriminations amounting to persecution against an individual. ${ }^{18}$

The EU's Council Directive on Minimum Standards for the qualifications and status of third country nationals and stateless persons as concerns connected to the potential violation of the European Court of Human Rights (Qualification Directive) was originally adopted in $2004{ }^{19}$ and recast in $2011 .^{20}$ It covers the criteria for being awarded international protection, and also the rights of recognised refugees as well as beneficiaries of subsidiary protection. Similar to Article 1F of the Refugee Convention, the 2004 Qualification Directive sets out reasons in which states may exclude persons from refugee status because the crimes they have committed are so serious that they do not deserve protection. The provisions on exclusion in Article 12 of the 2004 Directive went beyond the exhaustive criteria set out in the Refugee Protection, and thus a wider category of persons who would otherwise benefit from protection under the Refugee Convention are excluded. It adds language requiring the exclusion of those who "instigate or otherwise participate in" the types of crimes referenced in the article, 21 which can potentially lead states to exclude persons who lacked the intent to commit such crimes and thus could not be deemed individually responsible under international criminal law. ${ }^{22}$ The recast 2011 Directive has only slightly amended this wording - using 'incite' instead of 'instigate' 23 however it is not clear what difference the change in wording has made. The Court of Justice of the European Union has clarified in the case of $B$ and $D$, that neither the mere fact of an individual's membership in a terrorist group included on a list, nor the individual's intentional participation in the activities of a terrorist group, are in and of themselves sufficient to exclude automatically an applicant from refugee status. ${ }^{24}$

\section{II.2.2 Recognised refugees - exceptions to the obligation to avoid expulsions and refoulement}

The Refugee Convention also prevents expulsions and refoulement of persons who have already been determined to be refugees, safe for a few exceptions. Article 32 of the Convention prevents the expulsion of recognised refugees except 'on grounds of national security or public order'. ${ }^{25}$ Article 33(2) of the Convention prevents refoulement except of persons 'whom there are reasonable grounds for regarding as a danger to the security of the country in which he [or she] is, or who, having been convicted by a final judgement of a particularly serious crime, constitutes a danger to the community of that country.' A similar exception exists in the 1966 Principles Concerning Treatment of Refugees, adopted by the Asian-African Legal Consultative Committee, ${ }^{26}$ which provides in Article III(3) that 'No one seeking asylum in accordance with

\footnotetext{
${ }^{18}$ UNHCR, Background Note on the Application of the Exclusion Clauses: Article $1 F$ of the 1951 Convention relating to the Status of Refugees, Department of International Protection (DIP); Protection Policy and Legal Advice Section, 4 September 2003, para 84 ${ }^{19}$ Council Directive 2004/83/EC of 29 Apr 2004, OJ 30 Sept 2004, L 304/12.23

${ }^{20}$ Recast Qualification Directive, Directive 2011/95/EU of 13 December 2011

${ }^{21}$ Article 12(3) of the 2004 Qualification Directive

${ }^{22}$ Joined Cases C-57/09 and C-101/09, Germany v. B and Germany v. D, 9 November 2010

${ }^{23}$ Paragraph 12(3) of the 2011 Recast Qualification Directive

${ }^{24}$ Joined Cases C-57/09 and C-101/09, Germany v. B and Germany v. D, 9 November 2010

${ }^{25}$ Art 32(1); 33(2)

${ }^{26}$ Report of the Eighth Session of the Asian-African Legal Consultative Committee held in Bangkok, 8-17 Aug. 1966 , p. 335 (hereinafter 'Asian-African Refugee Principles')
} 
these Principles should, except for overriding reasons of national security or safeguarding the populations, be subjected to measures such as rejection at the frontier, return or expulsion.'

These exceptions - to the fundamental prohibition against expulsion and refoulement of refugees, respectively - are grave in their consequences and the threshold for their application is uniformly recognised to be high. Despite this, UNHCR has expressed concern that 'States may be inclined to expel groups or individuals based on religious, ethnic or national origin or political affiliation, on the mere assumption that they may be involved in terrorism' and has underscored that article 33(2) requires that it is established in the individual case that the person constitutes a danger to the security or the community of the country of refuge. ${ }^{27}$

Concerns have been expressed that Article 14 of the EU Qualification Directive, which provides that Member States may revoke, end or refuse to renew refugee status in certain circumstances, extends the grounds for exclusion beyond what is permitted by the Refugee Convention. Article 14(4) refers to reasonable grounds for regarding the person as a danger to the security of the Member State or if, having been convicted by final judgment of a particularly serious crime, they are a danger to the community. Article 14(5) permits Member States to apply Article 14(4) before a decision on the asylum claim has been made. These two provisions effectively allow refugee status to be denied (as a de facto form of exclusion) on security grounds and therefore for reasons that go beyond the (exhaustive) exclusion criteria set out in Article 1 (F) of the 1951 Refugee Convention. Under the Refugee Convention, security grounds are captured in Article $33(2)$ in relation to expulsion, not Article $1 \mathrm{~F}$ which concerns acts which predate the individual's entry to the host country. UNHCR has noted, in relation to Article 14 of the EU Qualification Directive that the provisions 'run the risk of introducing substantive modifications to the exclusion clauses of the 1951Convention.'28

\section{II.2.3 The absolute prohibition of torture as a form of added protection}

In refugee law, the prohibition of torture and other ill-treatment is typically considered at two critical junctures in the asylum process: as an act of persecution in refugee status determination under article 1 of the 1951 Convention relating to the Status of Refugees (Refugee Convention) and in the context of non-refoulement, i.e. the prohibition of sending someone to a country where he or she is at risk of persecution. ${ }^{29}$ International human rights law, in contrast, applies at all stages of the asylum-seeking process as any person regardless of their citizenship status has the right to be free from torture and other prohibited ill-treatment. ${ }^{30}$ Any state under whose jurisdiction a person falls, be it by virtue of being on its territory or under its effective control, has a corresponding duty to meet its obligations under the international prohibition of torture. ${ }^{31}$ This includes countries of origin, transit and destination.

\footnotetext{
${ }^{27}$ UNHCR, Addressing Security Concerns without Undermining Refugee Protection - UNHCR's perspective - Rev 1, http://www.un.org/en/sc/ctc/specialmeetings/2011/docs/unhcr-security-refugee-protection.pdf, para 21 ${ }^{28}$ UNHCR, Comments on the European Commission's proposal for a Directive of the European Parliament and of the Council on minimum standards for the qualification and status of third country nationals or stateless persons as beneficiaries of international protection and the content of the protection granted (COM(2009)551, 21 October 2009), p 13

${ }^{29}$ See Article 33 (1) of the Refugee Convention of 1951: 'No Contracting State shall expel or return ('refouler') a refugee in any manner whatsoever to the frontiers of territories where his life or freedom would be threatened on account of his race, religion, nationality, membership of a particular social group or political opinion'

${ }^{30}$ Art 3 of the UN Convention Against Torture; Art 7 of the International Covenant on Civil and Political Rights. The UN Human Rights Committee has clarified in its General Comment $N^{\circ} 20$ (1992) that states have an obligation not to expose individuals to 'the danger of torture or cruel, inhuman or degrading treatment or punishment upon return to another country by way of their extradition, expulsion or refoulement.' According to General Comment $\mathrm{N}^{\circ} 31$, Article 2 of the Covenant also entails an obligation on states 'not to extradite, deport, expel or otherwise remove a person from their territory, where there are substantial grounds for believing that there is a real risk of irreparable harm... either in the country to which removal is to be effected or in any country to which the person may subsequently be removed.'

${ }^{31}$ Committee Against Torture, General Comment No. 2: Implementation of Article 2 by states parties, UN Doc. CAT/C/GC/2, 24 January 2008, paras. 7, 16
} 
There will be instances in which an exclusion clause applies to an individual pursuant to Article $1 \mathrm{~F}$ of the Refugee Convention with the consequence that the person will not be recognised as a refugee, or where the exceptions to expulsion or refoulement apply in accordance with Articles 32(1) or 33(2) of that Convention, but nevertheless the person will be entitled to remain in the host state, because of operable residual human rights protections. The application of both these provisions is subject to a state's other obligations under human rights treaties which make clear that it is not possible to expel or refoule a person to a country where they face a real risk of torture or relate abuses. Human rights law allows for no derogations in this regard.

However, this has not prevented states from seeking to limit the application of human rights law to expulsion and refoulement cases which involve national security considerations, and a number of courts have struggled under this weight to maintain the absolute prohibition of refoulement when there is a real risk of torture. The absolute prohibition of torture allows for no balancing of the risk of torture against national security risks. If a state deports a person when the requirements in Article 33(2) of the Refugee Convention are met, it will still be a violation of the absolute prohibition of torture if there are substantial grounds for believing there will be torture on return. Despite this, the Canadian Supreme Court indicated in the Suresh case, that it was possible to expel a person who faced a real risk of torture, if there are reasonable grounds to believe that the person is a threat to national security of the country of refuge. The Supreme Court understood that in deciding a specific case, a balancing test must be carried out. If the risk the person in question imposes to Canada weighs more than the consequence of deporting the person, then Canada can deport a person even if there are substantial grounds to believe the person might be subject to torture on return. ${ }^{32}$ The UN Committee Against Torture noted as a subject of concern, ' $[\mathrm{t}]$ he failure of the Supreme Court of Canada, in Suresh v. Minister of Citizenship and Immigration, to recognize at the level of domestic law the absolute nature of the protection of article 3 of the Convention, which is not subject to any exception whatsoever.'33 The New Zealand Supreme Court came to a different conclusion, ${ }^{34}$ and determined that there should be no balancing or weighing of the threat posed with the rights to be free from torture. ${ }^{35}$ It held that '..., in deciding whether to certify ... that the continued presence of a person constitutes a threat to national security, and ..., in deciding whether to advise the Governor-General to order deportation .... , are not to so decide or advise if they are satisfied that there are substantial grounds for believing that, as a result of the deportation, the person would be in danger of being arbitrarily deprived of life or of being subjected to torture or to cruel, inhuman or degrading treatment or punishment.' 36

Some EU Member States have similarly sought to limit the extraterritorial nature of the prohibition of torture and ill-treatment to minimise its impact on expulsion cases. ${ }^{37}$ This approach was rejected by the European Court of Human Rights ${ }^{38}$ and UN treaty bodies. ${ }^{39}$ In Saadi, the Grand Chamber of the European Court of Human Rights made clear:

\footnotetext{
${ }^{32}$ See also, Ahani v Canada (Minister of Citizenship and Immigration) [2002] 1 SCR 72, para 22

${ }^{33}$ UNCAT, Consideration of reports submitted by states parties under article 19 of the convention, Conclusions and recommendations of the Committee against Torture (Canada), CAT/C/CR/34/CAN, 7 July 2005, para 4(a)

${ }^{34}$ Attorney-General v. Zaoui and Ors (Zaoui No. 2) [2005] NZSC 38, New Zealand: Supreme Court, 21 June 2005, para 93

35 Ibid, Para 42

${ }^{36} \mathrm{Ibid}$, para 93

${ }^{37}$ UK Government, New Vision for Refugees, 7 March 2010, 9, para. 3.3 (emphasis added), available at:

http://archiv.proasyl.de/texte/europe/union/2003/UK NewVision.pdf. See also, Observation of the Governments of Lithuania, Portugal, Slovakia and the United Kingdom Intervening in ECtHR, Application No 25424/05 Ramzy v the Netherlands (2005); Saadi v. Italy (Grand Chamber), Appl no 37201/06, 28 February 2008, para 122

${ }_{38}$ Chahal v United Kingdom ECtHR, Appl No 22414/93, 15 November 1996, para. 79 et seq.; Ahmed v Austria, Appl No 25694/9617, December 1996, para. 40 seq.; H.L.R. v France, Appl no 24573/94, 29 April 1997, para. 35; Saadi v Italy, Appl No 37201/06, 28 February 2008, para. 127; Sufi and Elmi v United Kingdom, Appl No 8319/0728, June 2011, para. 212 The Ahmed v Austria and Chahal v. UK cases make clear that expulsion is not permitted if there is a real risk of torture, even though Article 33(2) of the Refugee Convention may legitimately apply; the torture prohibition overrides.

${ }^{39}$ See also Committee Against Torture, Gorki Ernesto Tapia Paez v. Sweden, UN Doc CAT/C/18/D/39/1996, 28 April 1997, para 14.5
} 
138. Accordingly, the Court cannot accept the argument of the United Kingdom Government, supported by the Government, that a distinction must be drawn under Article 3 between treatment inflicted directly by a signatory state and treatment that might be inflicted by the authorities of another state, and that protection against this latter form of ill-treatment should be weighed against the interests of the community as a whole (see paragraphs 120 and 122 above). Since protection against the treatment prohibited by Article 3 is absolute, that provision imposes an obligation not to extradite or expel any person who, in the receiving country, would run the real risk of being subjected to such treatment. As the Court has repeatedly held, there can be no derogation from that rule (see the case-law cited in paragraph 127 above). It must therefore reaffirm the principle stated in Chahal (cited above, $\S 81$ ) that it is not possible to weigh the risk of ill-treatment against the reasons put forward for the expulsion in order to determine whether the responsibility of a state is engaged under Article 3, even where such treatment is inflicted by another state. In that connection, the conduct of the person concerned, however undesirable or dangerous, cannot be taken into account, with the consequence that the protection afforded by Article 3 is broader than that provided for in Articles 32 and 33 of the 1951 United Nations Convention relating to the Status of Refugees (see Chahal, cited above, $\S 80$, and paragraph 63 above). Moreover, that conclusion is in line with points IV and XII of the guidelines of the Committee of Ministers of the Council of Europe on human rights and the fight against terrorism (see paragraph 64 above).

139. The Court considers that the argument based on the balancing of the risk of harm if the person is sent back against the dangerousness he or she represents to the community if not sent back is misconceived. The concepts of "risk" and "dangerousness" in this context do not lend themselves to a balancing test because they are notions that can only be assessed independently of each other. Either the evidence adduced before the Court reveals that there is a substantial risk if the person is sent back or it does not. The prospect that he may pose a serious threat to the community if not returned does not reduce in any way the degree of risk of ill-treatment that the person may be subject to on return. For that reason it would be incorrect to require a higher standard of proof, as submitted by the intervener, where the person is considered to represent a serious danger to the community, since assessment of the level of risk is independent of such a test. ${ }^{40}$

States have also sought to limit or mitigate the risk of torture or other ill-treatment by negotiating diplomatic assurances with the receiving states in expulsion and deportation cases. This follows the longstanding practice of states which do not recognise the death penalty negotiating assurances in extradition cases that the death penalty will not be carried out. However, the sufficiency of assurances to guarantee that an individual will be adequately protected against ill-treatment is less clear-cut than in extradition cases where the person subject to the extradition warrant faces a potential death sentence. As noted by UNHCR, in death penalty cases (unlike torture cases), 'the wanted person is transferred to a formal process, and the requesting state's compliance with the assurances can be monitored. While there is no effective remedy for the requested state or the surrendered person if the assurances are not observed, non-compliance can be readily identified and would need to be taken into account when evaluating the reliability of such assurances in any future cases.' ${ }^{41}$ In torture cases, there is a usual lack of monitoring mechanisms or mechanism for the enforcement of the assurances post expulsion or deportation, nor is there any legal remedy for the sending state or the individual concerned in case of non-compliance, once the person has been transferred to the

${ }^{40}$ Saadi v. Italy (Grand Chamber), Appl no 37201/06, 28 February 2008

${ }^{41}$ UNHCR, 'Note on Diplomatic Assurances and International Refugee Protection', August 2006, para 22 
receiving state. ${ }^{42}$ The European Court of Human Rights has refrained from saying that diplomatic assurances are per se, an insufficient means to mitigate a real risk of torture.43 However, the bulk of international experts canvassing this issue have shown extreme reticence about the potential for such assurances to adequately minimise the risk of torture. The UN Special Rapporteur on Torture has noted that, in light of the risks, diplomatic assurances should never be resorted to in circumstances where there is a consistent pattern of gross, flagrant or mass violations of human rights, or of systematic practice of torture. ${ }^{44}$ In a later report, the Special Rapporteur has made clear that post-return mechanisms do little to mitigate the risk of torture and have proven ineffective in both safeguarding against torture and as a mechanism of accountability. 45 This is consistent with the views of many human rights organisations. For example, Amnesty International has called 'on the member states of the European Union (EU) and the Council of Europe to reject unequivocally the failed experiment of accepting unreliable, unenforceable promises of humane treatment from governments that torture and to recommit to comply with their absolute obligation not to send persons, no matter what their alleged crime or status, to places where they are at risk of torture and other ill-treatment. It is abundantly clear that promises of humane treatment in such circumstances simply cannot be trusted and they should no longer be used by European governments in an attempt to re-brand returns to the risk of torture as "human rights friendly" measures.' 46

Even when an individual manages to avoid expulsion or deportation by virtue of the operation of the absolute prohibition of torture, the status that person will have in the host state may be limited and is largely unregulated. They may not benefit from refugee status and all the rights that this may entail. They will have only limited rights to shelter and assistance. Given that Articles 1F, 32(1) and 33(2) apply to persons against whom there is credible evidence of wrongdoing but not necessarily a conviction for the offensive conduct, and given that the vast majority will not be prosecuted in the host state, they carry the weight of the suspicion nonetheless and exist in a state of limbo.

\footnotetext{
${ }^{22}$ Agiza v. Sweden, Comm No 233/2003, UN Doc CAT/C/34/D/233/2003, 20 May 2005; Mohammed Alzery v. Sweden, Comm No 1416/2005, UN Doc CCPR/C/88/D/1416/2005, 10 November 2006

${ }^{43}$ See, e.g., Othman (Abu Qatada) v. the United Kingdom, Appl No 8139/09, 17 January 2012

${ }^{44}$ Special Rapporteur on torture and other cruel, inhuman or degrading treatment or punishment, Report submitted pursuant to General Assembly resolution 58/164, UN Doc A/59/324, 1 September 2004, para 37

${ }^{45}$ Special Rapporteur on Torture, Report submitted in accordance with General Assembly resolution 59/182, UN Doc A/60/316, 30 August 2005, para 46

${ }^{46}$ Amnesty International, 'Dangerous Deals: Europe's reliance on "diplomatic assurances" against torture', AI Index: EUR

01/012/2010, April 2010, 7
} 


\section{Mass refugee influxes}

The challenges associated with mass refugee influxes have led to numerous arguments about the need to adapt, limit or exempt from the fundamental principles relating to non-refoulement (which is non-derogable). There are several arguments which have been put forward to justify a rewriting of the rules:

\section{The principle of non-refoulement does not apply to mass influx situations}

Is the principle of non-refoulement a non-derogable obligation even in cases of mass influx? The Refugee Convention contains no explicit exception for states to derogate from the principle of non-refoulement in cases of mass influx. Yet, the flight from generalised forms of violence in the context of war is not one of the grounds of persecution specifically recognised in the Refugee Convention. ${ }^{47}$ This is different than the wider grounds set out in the OAU Convention, ${ }^{48}$ which also recognises that the status of refugee 'shall also apply to every person who, owing to external aggression, occupation, foreign domination or events seriously disturbing public order in either part or the whole of his country of origin or nationality, is compelled to leave his place of habitual residence in order to seek refuge in another place outside his country of origin or nationality'49 or the Cartagena Declaration, ${ }^{50}$ which also recognises as refugees 'persons who have fled their country because their lives, safety or freedom have been threatened by generalized violence, foreign aggression, internal conflicts, massive violation of human rights or other circumstances which have seriously disturbed public order'. ${ }^{11}$ States outside these regions have generally not adopted these wider notions.

Nonetheless, the issue is not solely one of the breadth of the Refugee Convention. Many persons who flee conflict as part of a mass flight may have fears of persecution which fall squarely within the Refugee Convention. The challenge is that as a result of the mass influx, few states have the willingness and capacity to individually assess each entrant to determine the reasons for their flight. But, as Durieux and McAdam set out, 'to assert that the Convention does not apply in cases of mass influx is tantamount to saying that the individual and his or her rights is absent when that individual is part of a mass group.'52 Lauterpacht and Bethlehem have similarly explained that ' $[t]$ he words of Article 33(1) give no reason to exclude the application of the principle to situations of mass influx. On the contrary, read in the light of the humanitarian object of the treaty and the fundamental character of the principle, the principle must apply unless its application is clearly excluded.'53 Lauterpacht and Bethlehem also refer to the OAU Refugee Convention, ${ }^{54}$ the Cartagena Declaration ${ }^{55}$ and the proposal for an EU Council Directive

\footnotetext{
${ }^{47}$ Art 1(A)(2) of the Refugee Convention read together with the 1967 Protocol recognises as a refugee a person with a 'well-founded fear of being persecuted for reasons of race, religion, nationality, membership of a particular social group or political opinion, is outside the country of his nationality and is unable or, owing to such fear, is unwilling to avail himself of the protection of that country; or who, not having a nationality and being outside the country of his former habitual residence as a result of such events, is unable or, owing to such fear, is unwilling to return to it...'

48 Convention Governing the Specific Aspects of Refugee Problems in Africa, Organization of African Unity (OAU) (adopted 10 September 1969, entered into force 20 June 1974) 1001 UNTS 45

49 Ibid, Art 1(2)

${ }^{50}$ Cartagena Declaration on Refugees, Adopted by the Colloquium on the International Protection of Refugees in Central America,

Mexico and Panama, Cartagena de Indias, Colombia, 22 November 1984

51 Ibid, III(3)

${ }^{52}$ Jean-Francois Durieux and Jane McAdam, 'Non-Refoulement through Time: The Case for a Derogation Clause to the Refugee

Convention in Mass Influx Emergencies' (2004) 16 Intl J Refugee L 4, 9

${ }^{53}$ Sir Elihu Lauterpacht and Daniel Bethlehem, 'The scope and content of the principle of non-refoulement: Opinion', in Erika Feller,

Volker Türk and Frances Nicholson (eds) Refugee Protection in International Law: UNHCR's Global Consultations on International

Protection (Cambridge University Press, 2003) paras 103-4

54 OAU, Convention Governing the Specific Aspects of Refugee Problems in Africa, Art II(3)

55 OAS, Cartagena Declaration on Refugees, Conclusion III(5)
} 
on Temporary Protection ${ }^{56}$ all of which recognise the fundamental character of nonrefoulement. 57

\section{Temporary recognition of refugee status does not confirm refugee status, so non- refoulement does not apply}

While host states may apply different standards in contexts of mass refugee influxes to determine whether persons may be entitled to stay (use of prima facie determinations), there is no indication that persons which have received such determinations benefit from less rights on entry. Prima facie status simply raises a presumption that the individual members of the group are refugees, who can accordingly benefit from international protection and assistance. It is conclusive of refugee status, unless the state decides to subject the person to scrutiny on an individual basis, and finds against the individual asylum seeker. ${ }^{58}$

\section{The presumption of durable solution does not apply to mass influx situations}

When an individual is recognised as a refugee, there is an obligation on the receiving state to ensure that the person benefits from a durable solution, whether it consists of voluntary repatriation, local integration or resettlement. The argument is that this obligation to find a durable solution does not apply to individuals who arrive as part of a mass influx. Yet the political failure of states to work in coordination to find and take the necessary measures to adopt such solutions does not mean that they have no obligation to find such solutions. ${ }^{59}$ Not only do the obligations continue to apply as a matter of law, there are cogent humanitarian reasons why durable solutions are vital. An absence of durable solutions intensifies refugees' vulnerability and risks of exploitation and increases long-term dependency on humanitarian support. Inside refugee camps and enclosed immigration detention settings, refugees are vulnerable to physical violence, torture, sexual assault and rape. The vulnerability, insecurity and lack of safe options can lead refugees to resort to dangerous and at times lifethreatening courses of conduct such as use of smugglers and traffickers, or returning to the unsafe conflict zones from which they fled. In certain circumstances, the failure to afford a durable solution may amount to a form of cruel, inhuman or degrading treatment. If it a cause for an involuntary return, it may also constitute a form of refoulement. It is thus difficult to easily separate out the fundamental non-refoulement obligation from the host of other obligations incumbent on states in accordance with the Refugee Convention. It has been argued that setting up some kind of derogation system would better protect refugees in a mass influx situation, given the tendency of many states to simply ignore many of the obligations in the Refugee Convention. 60 This may not be prudent, given the interrelationship between the different Convention rights.

\footnotetext{
${ }^{56}$ Council Directive on minimum standards for giving temporary protection in the event of a mass influx of displaced persons and on measures promoting a balance of efforts between Member States in receiving such persons and bearing the consequences thereof, 2001/55/EC, 20 July 2001, Article 6(2)

57 Lauterpacht and Bethlehem (n. 53), paras. 107-8

58 Discussed in Durieux and McAdam (n. 52), 12-13

${ }^{59}$ Ibid, 13

${ }^{60}$ Ibid, 18-23
} 


\section{The Trajectory of Harm}

\section{IV.1 Taking flight - the precursors}

There is a view popularised in certain media outlets that those leaving their countries of origin have some kind of choice. The reality is quite different. Most have found the transition out of their countries extremely difficult, miss the support structures and would return if they could. As M. Singh who comes from Punjab says, 'I miss my family who are still in India and I'm not coping myself so I couldn't have a family of my own. It's hard because back in India I was a local priest, people respected me, here I'm by myself, I have no one.' 61

Millions are fleeing simply because they wish to survive; something which has become an impossible prospect in their home countries. As one academic indicated in respect of Burmese refugees, '[t]he Rohingya are faced with two options: stay and face annihilation, or flee.'62 Individuals are fleeing intractable and devastating conflicts, sectarianism and fundamentalism, indiscriminate bombings, laying siege to villages hindering access to water and food, persecution, rapes, lashings and extrajudicial executions. They have a fear for their continued safety, which prompts their flight. Sometimes they leave because state institutions have collapsed and they fear that their governments cannot protect them from the acts of rebel movements, criminal gangs or other non-state actors. Many have been victims of or witnessed multiple acts of violence including torture, which can produce lasting psychological impacts.

Eritrea, one of the largest refugee producing countries in Africa has been described by the UN as a place where 'Eritreans continue to be subjected to indefinite national service, arbitrary detention, torture, enforced disappearances, reprisals for the alleged conduct of family members, discrimination on religious and ethnic grounds, sexual and gender-based violence, and killings.' 63 It determined amongst other things that 'the use of torture by Eritrean officials has been, and remains, both widespread and systematic in civilian and military detention centres.' 64

An assessment of Syrian refugees in Jordan revealed that as a result of their experiences $26 \%$ felt 'so hopeless they did not want to carry on living' and almost 19\% felt 'unable to carry out essential activities for daily living because of feelings of fear, anger, fatigue, disinterest, hopelessness, or upset.' 65 A recent study by the German chamber of psychotherapists found similarly. 66 The study determined that at least half of the refugees in Germany suffered from psychological problems such as post-traumatic stress disorder or depression. $40 \%$ have had suicidal thoughts or have tried to kill themselves. The study refers by way of example to the plight of Yezidi women who escaped from captivity of the Islamic State, who experienced during their flight to Germany flashbacks and panic attacks with palpitations, shortness of breath, dizziness and fear of death. The narrowness of the plane sparked memories of the captivity.

\footnotetext{
${ }^{61}$ REDRESS, Torture: Stories of Survival, June 2005, 11

62 Emma Graham-Harrison, 'Burma's boatpeople "faced choice of annihilation or risking their lives at sea"', The Observer, 17 May 2015

63 UN Human Rights Council, 'Report of the commission of inquiry on human rights in Eritrea', UN Doc A/HRC/32/47, 9 May 2016, para 29

64 Ibid, para 39

${ }^{65}$ L. James, et al. 'The Mental Health of Syrian Refugee Children and Adolescents' (2014) 47 Forced Migration Review $42-44$

${ }^{66}$ See, 'Mindestens die Hälfte der Flüchtlinge ist psychisch krank', BPtK-Standpunkt Psychische Erkrankungen bei Flüchtlingen, 16 September 2015, http://www.bptk.de/aktuell/einzelseite/artikel/mindestens-d.html
} 


\section{IV.2 In transit - perilous journeys}

When refugees leave their homes, they can face extreme dangers. Many refugees leave their homes suddenly and are able to take very few if any of their possessions with them. Sometimes they face many days, weeks or even months or years of travel, with little food, medicines, lack of shelter and appropriate clothing and are in fear for their lives. The elderly, disabled persons and young children suffer particularly given the harsh conditions. Refugees become walking targets for armed gangs and marauders who rob them of their few last possessions and bribe them to secure safe passage. Young boys can be susceptible to kidnap and forced to fight for armed groups; women and girls are regularly subjected to rape.

\section{Displaced internally and in neighbouring countries}

Most persons forced to leave their homes have the intention of returning. They may move to other parts of their home country they perceive as safer or to neighbouring countries where they may have friends or relatives, or which may be easiest for them to access. UNHCR has determined that 'the majority of refugees were able to find asylum in neighbouring countries. Of the 10.1 million refugees from the five highest countries of origin, all but 1.1 million $(11 \%)$ found safety in a neighbouring country. This is the case for most of the refugee populations of concern to UNHCR.' ${ }^{67}$ In $2015,86 \%$ of the world's refugees were being hosted by developing countries; the least developed countries hosted $26 \%$ of the world's refugees. ${ }^{68}$ Neighbouring host states face a significant challenge to cope with large influxes of refugees, particularly when the reasons for the displacement are protracted.

Many of these refugees are hosted in makeshift camps, often for years and sometimes decades and even generations. The situation in camps can be devastating. There is often inadequate food, medicine and protection from the cold. Because some of the host countries do not recognise refugee status or offer the possibility of local integration, the inhabitants await an answer on resettlement to another country, which can take years and does not always come. There are not always educational opportunities in the camps which can be devastating for children refugees who remain idle, together with their idle families who cannot work and are wholly dependent on humanitarian aid. Safety in camps can also be problematic, with generalised violence being rife, endemic sexual violence, and in some cases armed factions and criminal gangs being allowed to operate. ${ }^{69}$

One volunteer serving at the Softex camp [in Greece], which holds 1,400 mostly Syrian refugees, alleged that some young girls had been effectively groomed by male gangs. He said an Iraqi family had to be moved to emergency accommodation outside the camp after their daughter was attacked.

"The parents are still in disbelief over what happened. A man from one of the 'mafia' groups asked their seven-year-old daughter into their tent to play games on his phone and then zipped up the tent. She came back with marks on her arms and neck. Later the girl described how she was sexually abused. It has scarred a seven-year-old child for life," said the volunteer, who asked to remain anonymous.70

\footnotetext{
67 UNHCR, Global Trends: Forced Displacement 2015, 21

68 Ibid, 2

${ }^{69}$ A refugee from Dadaab refugee camp in Kenya, the largest camp in the world, writes in 2010: 'Our lives in the camps are far worse than you can imagine. We live in an open prison, far away from justice and humanity. We talk, but our voices are never heard. We move, but only inside a cage. We have many skills and talents, but we are denied our chance to maximize our potential. We are chained to a life full of stress and despair; a life for which many would prefer death. We are denied opportunities for education and employment. We live in a condition without adequate water, food, or health facilities. We are arbitrarily beaten or detained by police within the confines of the camp. We lack the ability to freely express ourselves or have control over the decisions affecting our lives.' Contributor, 'Kenya: A Voice from the voiceless: Dadaab refugee camps', Pambazuka News, 16 April 2010

${ }^{70}$ Mark Townsend, 'Sexual assaults on children' at Greek refugee camps, the Observer, 13 August 2016
} 
Those refugees that live outside of camps often live fringe existences, as quasi-criminals dodging detention, usually unable to enter the labour market and having to rely on handouts, often without basic necessities. Refugees, including many children are forced to enter informal labour markets, leading to exploitation and further risk.

\section{Travelling further afield}

The desperate conditions in neighbouring countries and the progressive loss of hope of returning home leads many refugees to look for options further afield. Many refugees seek to leave the camps, or bypass them altogether, looking somewhere for more permanent refuge.

As lawful arrival by air has become increasingly difficult because of visa and carrier restrictions, many refugees use either land routes or travel by sea, or both. People pay smugglers significant amounts of money to travel on unseaworthy vessels is because they are legally prohibited, via these visa restrictions and carrier sanctions, from taking the safer and usually much cheaper options of regular sea vessels and flights.

Due to restrictive immigration regimes in place, they must often have recourse to smugglers to reach their destination country, at least for some part of their journey. Refugees and other migrants pay smugglers exorbitant sums for the privilege of travelling using unseaworthy vessels or suffocating containers or sealed compartments hidden in trucks or vans. Smugglers, whose actions are illegal under both international and most national laws, ${ }^{71}$ have regularly abused asylum seekers and migrants or left them in dangerous situations, at times in collusion with officials. ${ }^{72}$ In some cases, refugees and other migrants may actually be trafficked, i.e. coerced and exploited. ${ }^{73}$

There are a number of transit routes which vast numbers of refugees have used, each with their own dangers. The usage rates for these routes have changed over time, and have depended on the opening and closure of borders and other hardships along the way. Some of these routes are summarised below.

\section{i. Eritreans and others from the Horn of Africa through Egypt and the Sinai Desert towards Israel}

For "Adam", a 31-year-old asylum seeker in Israel who fled Eritrea after being incarcerated and tortured for leaving military service without permission, life has been filled with uncertainty almost as long as he can remember. While crossing the Sinai Desert, Adam was taken for ransom by Bedouin smugglers; he suffered extensive beatings and torture before his family was able to pay the requested sum. After crossing the border to Israel he was placed in the Saharonim detention facility for three months. ${ }^{74}$

Many Eritreans and nationals from some other states in the Horn of Africa have taken a route through Ethiopia, Sudan and Egypt through the Sinai desert with the hopes of reaching Israel and other countries. Others were seeking to reach other destinations in the region or were based in refugee camps but were abducted by traffickers and re-routed to the Sinai and towards

\footnotetext{
71 Protocol against the Smuggling of Migrants by Land, Sea and Air, supplementing the United Nations Convention against Transnational Organised Crime, 2000. See further Anne T. Gallagher and Fiona David, The International Law of Migrant Smuggling (Cambridge University Press, 2014)

72 UNODC, Issue Paper: Smuggling of Migrants by Sea (2011), 20, 23-24

${ }^{73}$ Human Rights Watch, "I Wanted to Lie Down and Die:" Trafficking and Torture of Eritreans in Sudan and Egypt', 11 February 2014

74 Zhanna Veyts, 'A Reprieve for Eritrean Asylum Seeker in Israel', 6 February 2015, http://www.hias.org/blog/reprieve-eritreanasylum-seeker-israel
} 
Israel. ${ }^{75}$ While crossing the Desert, many are held for ransom by smugglers and traffickers are subjects to makeshift detention and torture (sometimes resulting in death) until families are able to pay the requested sums. According to Human Rights Watch, these criminal gangs have perpetrated 'rapes of both women and men; electric shocks; burning victims' genitalia and other body parts with hot irons, boiling water, molten plastic, rubber, and cigarettes; beating them with metal rods or sticks; hanging victims from ceilings; threatening them with death; and depriving them of sleep for long periods.' Seventeen of the victims said they saw others die of the torture. ${ }^{76}$ Refugees attempting to cross the border between Egypt and Israel have reportedly been shot at, some of them killed. ${ }^{77}$

\section{ii. Sub-Saharan Africans to Libya towards Italy}

We walked west, into Sudan, to Khartoum, then into the Sahara and into Libya. There were a hundred and thirty-one of us. This is the story that we told later, to the police, the journalists, and the courts. One day in Libya, a band of armed Somalis came upon us. They forced us into vans and brought us to the town of Sabha, where they locked us up in a house. They made us stand for hours. They tied us upside down and beat the soles of our feet. They held weapons to our heads and fired bullets into the floor. They drove two of our young women into the desert, raped them, and returned with only one. They poured water over the floor and tried to shock us with a live wire, but they succeeded only in burning out the lights.

The Somalis wanted a ransom of thirty-three hundred dollars a head. Two weeks later, most of our families had paid, so they drove us to Tripoli. They took us to the smuggler Ermias. He was dark-skinned, around thirty, well fed. He took sixteen hundred dollars from each of us to arrange a boat to Lampedusa. It's an Italian island about a day off the Libyan coast. Many of us had never seen the sea and did not know how to swim. We asked if we could pay extra for life jackets; Ermias refused. His men locked us in a warehouse with many others, where we waited through the month of September, 2013. On October 2nd, hours before dawn, they drove us to the shore and ferried us out to a boat, sixty-five feet long. They packed more than five hundred of us onto the bridge and the deck and down in the cabins. The smugglers did not like the look of the boat, so heavy and low in the water, and so old. But they said, "God willing, you will be lucky."78

Those refugees that reach Libya with the ultimate objective of sailing to Italy face extreme hardship in the country. Libya is not party to the Refugee Convention, and has been repeatedly criticised for its failure to respect the rights of refugees, including the prohibition of refoulement. ${ }^{79}$ Libya also has a poor record of protecting human rights, particularly the prohibition of torture, both during and after the Ghaddafi regime. Since 2011, the conduct of militias and other forces have spiralled out of control, and the administration of justice is weak

\footnotetext{
${ }^{75}$ Bahlbi Y. Malk, 'Human Trafficking and Human Smuggling to and from Eastern Sudan: Intended and Unintended Consequences of States' Policies' (2016) 5(1) Academic Journal of Interdisciplinary Studies, 215

${ }^{76}$ HRW, 'Egypt/Sudan: Traffickers Who Torture - Egypt Should Use Sinai Security Operations to Suppress Trafficking', 11 February 2014. A trafficker reportedly explained to HRW: 'The longest I held someone was seven months and the shortest was one month. The last group was four Eritreans and I tortured all of them. I got them to call their relatives and to ask them to pay $\$ 33,000$ each. Sometimes I tortured them while they were on the phone so the relatives could hear them scream. I did to them what I do to everyone. I beat their legs and feet, and sometimes their stomachs and chest, with a wooden stick. I hang them upside down, sometimes for an hour. Three of them died because I beat them too hard. I released the one that paid. About two out of every 10 people I torture pay what I ask. Some pay less and I release them. Others die of the torture. Sometimes when the wounds get bad and I want them to torture them more, I treat their wounds with bandages and alcohol...' HRW, "I Wanted to Lie Down and Die" Trafficking and Torture of Eritreans in Sudan and Egypt, 11 February 2014

77 Patrick Strickland, 'Sudanese refugees shot dead on Egypt-Israel border', Al Jazeera, 15 November 2015

${ }^{78}$ Mattathias Schwartz, 'Letter from Lampedusa: The Africans who risk all to reach Europe look to an exiled priest as their savior', The New Yorker, 21 April 2014

${ }^{79}$ Hirsi Jamaa v. Italy, ECtHR, App. No. 27765/09 (Grand Chamber), 23 February 2012, paras. 153-56
} 
to non-existent. The prevailing chaos has resulted in widespread violations, including racial discrimination and xenophobic attacks, committed with impunity. ${ }^{80}$

Some refugees are abducted and controlled by criminal gangs of smugglers and subjected to various forms of torture in order to secure bribes and complicity. Others are detained and held by one or other of the Libyan militia groups operating in the country or by centres operating under the guise of the State's Department to Combat Irregular Migration, many of which are controlled by armed groups. In detention, refugees face regular torture, inhuman conditions and the prospect of indefinite detention. A series of reports issued by Human Rights Watch based on interviews with (former) detainees document what happened to them in the centres of Gharyan, Kufra and Sabha, which Italy had funded and helped to build as part of earlier collaboration with Libya in 2003 and 2004.81 The Gharyan and Kufra centres are located in isolated areas. Conditions are extremely poor and several detainees are reported to have been subjected to torture, including being beaten with metal bars and plastic tubes when trying to escape, being administered electric shocks, subjected to sexual abuse and discriminatory ill-treatment of nonMuslims. ${ }^{82}$

Those that manage to avoid detention are in constant fear of arrest, unable to work but at the same time needing to find a way to survive and to secure the exorbitant costs for their perilous sea voyages. Libyan coastguard officials have intercepted boats destined for Italy, subjected the passengers to ill-treatment and returned the passengers to Libya where they were subjected to inhuman detention conditions. ${ }^{83}$ According to the UN Office of the High Commissioner for Human Rights, refugees and other migrants are also subjected to violence in 'connection houses' where they can stay for a month, while awaiting departure to Europe. Many are tortured to extract more money, they are given meagre food rations to reduce weight for the journey, and women are taken away and raped. ${ }^{84}$

In 2008, Italy and Libya signed the Treaty of Friendship, Partnership and Cooperation, which, inter alia, envisaged cooperation to intensify border controls; stop terrorism; crime; trafficking and smuggling of illegal migrants. The cooperation envisaged funding to Libya by both Italy and the EU. ${ }^{85}$ Notably, the treaty was framed in terms of security threats and criminal activities but inevitably affected asylum seekers fleeing persecution. ${ }^{86}$ It was premised on the desire to curb smuggling, but served the underlying purpose of deterring migration. ${ }^{87}$

Following the fall of the Ghaddafi regime, Italy entered into new agreements with Libya in $2011^{88}$ and in April 2012.89 The latter agreement addresses training for Libyan security forces, reception, monitoring the borders, as well as voluntary return and repatriation, population

\footnotetext{
${ }^{80}$ Report of the United Nations High Commissioner for Human Rights on the situation of human rights in Libya and on related technical support and capacity-building need, UN Doc HRC/28/51, 12 January 2015

81 Human Rights Watch, Libya: Whipped, Beaten, and Hung from Trees Detained Migrants, Asylum Seekers Describe Torture, Other Abuse in Detention, 22 June 2014. See further on immigration detention in Libya, Amnesty International, 'Libya is full of cruelty': Stories of abduction, sexual violence and abuse from migrants and refugees, May 2015, 19-23

${ }^{82}$ Human Rights Watch, ibid

${ }^{83}$ Amnesty International, 'EU risks fuelling horrific abuse of refugees and migrants in Libya', 14 June 2016

${ }^{84}$ UN Support Mission in Libya, 'Report on the Human Rights Situation in Libya', 16 November 2015, 25-26

85 Treaty of Friendship, Partnership and Cooperation between the Italian Republic and the Great Socialist People's Libyan Arab Jamahariya, 30 August 2008

${ }^{86}$ Many refugees in Libya come from states in the midst of conflict and/or with a record of persecution as well as other torture and ill-treatment, such as Eritrea, Iraq, Somalia, Sudan and Syria

${ }^{87}$ See in particular, Emanuela Paoletti and Ferruccio Pastore, 'Sharing the Dirty Job on the Southern Front? Italian-Libyan Relations on Migration and Their Impact on the European Union', University of Oxford, International Migration Institute, Working Papers, Paper 29 (December 2010); Hirsi Jamaa v. Italy, ECtHR, App. No. 27765/09 (Grand Chamber), 23 February 2012, paras. 19-21, which describe two bilateral agreements entered into in 2007 and 2009 and make brief reference to the 2008 treaty of friendship, partnership and cooperation.

${ }^{88}$ Statewatch, 'ASGI Questions the Lawfulness of Italy's Agreement with the NTC - Serious Doubts about the Lawfulness of the Agreement between the Government and the Libyan NTC', 20 June 2011, at www.statewatch.org/news/2011/jun/04italy-libyaasgi.htm

${ }^{89}$ Minutes of the Meeting between the Minister for the Interior of the Italian Republic and the Minister for the Interior of Libya (Tripoli, 3 April 2012) (unofficial translation on file with REDRESS)
} 
register and mechanisms for follow-up. It is aimed at combating "illegal immigration" and makes scant reference to respect for refugee rights and human rights. Indeed, by using the term "illegal" immigration, and not "refugees" or "asylum-seekers", the agreement suggests that all immigration is "illegal" and implies that none of the persons entering Libya has a valid claim to refugee status. In respect of activities against "illegal" immigration and stay of "illegal immigrants" in detention centres "the parties confirm their commitment to respect human rights protected by international conventions and agreements that are in force. ${ }^{\prime 90}$ However, the agreement does not specify how that respect will be ensured and does not provide for any monitoring or accountability mechanism in case of breach.

In 2012, the European Court of Human Rights determined that Italy violated the prohibition against torture amongst other violations when it intercepted migrant boats on the high seas and returned them to Libya. ${ }^{91}$ The case concerned the interception by Italy of three boats in the Maltese Search and Rescue area 35 nautical miles south of Lampedusa. Italian patrol boats sent 230 migrants back to Libya, in accordance with Italy's bilateral agreement with Libya. The Hirsi Jamaa ruling made clear that the principle of non-refoulement applied to the High Seas.

The Hirsi Jamaa ruling makes clear that Italy's co-operation with Libya can and has been incompatible with the prohibition of refoulement to torture. Equally, torture and other illtreatment in Libyan detention centres raise the question of whether Italy's policy, particularly the financial support provided to build and maintain such centres, triggers its wider responsibility under international law. Italy has provided largely material support and supported capacity building. However, Italian authorities are not present in detention centres and do not direct or control Libyan authorities or militias in detention settings. Nonetheless, Italy may be responsible for complicity for aiding or assisting another state in the commission of an internationally wrongful act by the latter under general principles relating to state responsibility. Aiding and assisting has been understood to include providing funding..$^{92}$ There is no evidence to suggest that Italy has cooperated with the intention to aid or assist Libya to breach the prohibition of torture. However, both at the time when the detention centres were built in 2003 and 2004 and following the fall of the Ghaddafi regime, allegations of widespread torture in Libya were public knowledge, also based on UN reports. ${ }^{93}$ Italy therefore provided financial assistance for the building and maintenance of detention centres, and continued its cooperation with Libya, arguably knowing that it would contribute to a practice of apprehending refugees and other migrants who were at a serious risk of ill-treatment or torture at the hands of Libyan authorities or militias. Beyond Italy's formal responsibility, its funding and other support to Libya in relation to migrant detention also raises broader concerns over a policy that helps create and perpetuate an environment in which torture is rife, without ensuring that adequate safeguards are in place.

Following several widely publicised boat capsizes off of Lampedusa, in 2014 the Italian navy began to operation a search and rescue operation - Mare Nostrum, which was responsible for saving many thousands of lives. It was later replaced by Triton, run by the EU border agency Frontex, which has a much more limited scope of operation (50km off the Italian coast) and thus has been less effective in preventing deaths.

\footnotetext{
90 Ibid

${ }^{91}$ Hirsi Jamaa v. Italy, ECtHR, Appl No. 27765/09 (Grand Chamber), 23 February 2012

${ }^{92}$ ILC, Draft articles on Responsibility of States for Internationally Wrongful Acts, with commentaries 2001, 67, 'provides material aid to a State that uses the aid to commit human rights violations.'

${ }^{93}$ See in particular, Concluding observations of the Committee against Torture on Libya, UN Doc A/54/44 (SUPP) (1999), paras. 176-189; Concluding Observations of the Human Rights Committee on Libya, UN Doc CCPR/C/LBY/CO/4, 15 November 2007, para. 15; Report of the International Commission of Inquiry on Libya, UN Doc A/HRC/19/68, 8 March 2012, paras. 44-53; Report of the United Nations High Commissioner for Human Rights on the situation of human rights in Libya and on related technical support and capacity-building needs, UN Doc A/HRC/28/51, 12 January 2015, paras. 32-34
} 


\section{iii. Mainly Syrian, Afghan and Iraqi refugees to Turkey then the Aegean Sea towards Greece and onwards to other countries in Europe}

Another route to Europe, mainly for Syrians, Iraqis, Afghans and some Iranians has been through Turkey to Greece and beyond. Few refugees have the intention to stay in Greece; from Greece, refugees have sought to travel onward through the western Balkans (until that route was closed) due north for Germany and other countries assumed to be more receptive to refugees.

Turkey hosts over two million Syrian refugees and has been part of the principle route for refugees fleeing Syria. While in principle, Syrians crossing directly into Turkey to flee the conflict are allowed entry, there have been reports of restrictions and pushbacks. Turkey does not recognise the Syrian refugees as such but rather as temporary "guests" and subsequently entitled to a temporary protection regime which does not entitle the individuals to apply for refugee status. This is because while Turkey ratified the Refugee Convention and its 1967 Protocol, it only recognises refugees originating from countries which are members of the Council of Europe.

Smuggling networks have facilitated the voyage from Turkey to Greece, using unseaworthy and overcrowded vessels leading to capsizes and many deaths.

On arrival in Greece, refugees face further hardships. There is insufficient infrastructure to deal with the humanitarian needs of large numbers of refugees, made much worse since the closure of borders of neighbouring countries, making onward movement impossible. Furthermore, there are insufficient personnel to process the vast numbers of asylum claims. Even before those border closures, the European Court of Human Rights had ruled that returns to Greece from other countries in Europe under the Dublin regulation ${ }^{94}$ would subject the individuals to cruel, inhuman or degrading treatment on account of the poor conditions of his detention and living conditions. ${ }^{95}$ These findings were echoed by the UN Special Rapporteur on the Human Rights of Migrants' concerns over detention in Greece:

Irregular migrants are detained up to several months in various establishments, such as police stations, border guard stations and coast guard facilities, which are clearly not suitable for long-term detention. There are also some dedicated migration detention centres, some of which are converted military camps or police academies. As common standards are not applied, the detention conditions and the safeguards available vary significantly in the different establishments and locations. The Special Rapporteur visited 11 detention facilities in Greece. In general, detention conditions at all [sic] were inappropriate. Migrants were locked in their cells for most of the day with no activities to keep them occupied. Several of the detention centres did not have fenced-in outdoor areas, thus police officers were reluctant to letting the migrants go outside at all, as they risk disciplinary action if a migrant escapes. The conditions at Venna detention centre were particularly poor, and the Special Rapporteur was pleased to hear that this centre closed down shortly after his visit.

In some of the detention facilities, the migrants had limited access to toilets; some facilities had no artificial lighting so that during the

\footnotetext{
94 The Dublin III regulation, EU No 604/2013, establishes “criteria and mechanisms for determining the Member State responsible for examining an application for international protection lodged in one of the Member States by a third-Country national or a stateless person", whereby the state in which an asylum seekers first arrives bears responsibility for processing claims.

${ }_{95}$ M.S.S. v Belgium and Greece (Grand Chamber), Appl no 30696/09, 21 January 2011, paras. 362-68
} 
winter, migrants were in the dark from early afternoon. Most of the detention facilities visited lacked heating and hot water and the detainees complained about insufficient amounts and poor quality of food, lack of soap and other hygiene products, as well as insufficient clothing, shoes and blankets. ${ }^{96}$

The European Union's response to the growing crisis was to strike a deal with Turkey aimed at returning all persons irregularly entering the Greek islands after 20 March 2016 to Turkey. As part of the deal, Turkey was deemed a "safe third country", which has been highly disputed. ${ }^{97}$ But UNHCR's Executive Committee has concluded that an asylum-seeker whose claim has yet to be determined from the territory of the country where the claim has been submitted should only be returned to a third country if it should be established that the third country will treat the asylum-seeker(s) in accordance with accepted international standards, such as ensuring effective protection against refoulement, and will provide the asylum-seeker(s) with the possibility to seek and enjoy asylum. This conclusion applies to all scenarios including pursuant to bilateral or multilateral readmission agreements. ${ }^{98}$ As part of this deal, one refugee in Europe is sent to Turkey, and in exchange, one refugee is taken from a camp in Turkey and resettled to Europe. It is unclear how this scheme will work following the recent coup attempt in Turkey and the worsening security and human rights situation in the country.

\section{iv. Burmese Rohingya in the Andaman Sea towards Thailand and Malaysia towards other destinations in Asia}

There has been a mass exodus of the Burmese Rohingya minority on account of the persecution they face in the country. Many have embarked on perilous journeys by boat, with the aid of traffickers and other corrupt middlemen. Women are often raped on the boats or are forced into marriage with men who pay for their journey. According to one passenger, who watched her brother die when fighting broke out after the captain of their wooden boat fled on a speedboat, leaving more than 800 passengers adrift with dwindling food and water: 'If I had known the boat journey would be so horrendous, I would rather have just died in Myanmar [Burma].'99 Some of the boats were simply left to drift at sea with Governments in the region often refusing the boats permission to land. Indonesia and Malaysia agreed to take a number of the refugees ashore, though many refugees remain detained. ${ }^{100}$

Some of the refugees have been held by traffickers in torture camps along the Thai - Malay border until a ransom is paid for their freedom. Mass graves have reportedly been located in Malaysia, ${ }^{101}$ which has led to a landmark criminal trial of 92 traffickers in Thailand. ${ }^{102}$ Despite this, Thailand has reportedly refouled numerous Rohingya back to Burma without proper scrutiny of their claims. ${ }^{103}$

\footnotetext{
${ }^{96}$ Report by the Special Rapporteur on the human rights of migrants, François Crépeau, Addendum: Mission to Greece, UN Doc A/HRC/23/46/Add.4, 17 April 2013, paras.48, 49

${ }^{97}$ Danish Council for Refugees and European Council on Refugees and Exiles, 'DCR/ECRE desk research on application of a safe third country and a first country of asylum concepts to Turkey', May 2016; Amnesty International, 'EU's reckless refugee returns to Turkey illegal' 3 June 2016; Steve Peers, 'The final EU/Turkey refugee deal: a legal assessment' 18 March 2016, available at: http://eulawanalysis.blogspot.co.uk/2016/03/the-final-euturkey-refugee-deal-legal.html; HRW, 'EU: Turkey Mass-Return Deal Threatens Rights' 15 March 2016; Médecins sans frontiers, 'Europe, don't turn your back on Asylum: \#TakePeopleIn’ 13 May 2016 98 UNHCR. Executive Committee Conclusion No. 85 (XLIX) - 1998, (aa)

${ }^{99}$ Emma Graham-Harrison, 'Burma's boatpeople "faced choice of annihilation or risking their lives at sea", 'The Observer, 17 May 2015

${ }^{100}$ Patrick Kingsley, 'Rohingya trafficking victims stuck in captivity, one year on', the Guardian, 27 May 2016

101 Praveen Menon, 'Malaysia finds 139 graves, signs of torture in human trafficking camps', Reuters, 25 May 2015

102 'Major Human Trafficking Trial Begins in Bangkok', Chiangrai Times, 15 March 2016

${ }^{103}$ Asylum Access and Asia Pacific Refugee Rights Network, 'Report on the Implementation of the International Covenant on Civil and Political Rights with Regard to the Rights of Urban Refugees and Asylum Seekers and Rohingya Refugees and Asylum Seekers in Thailand', Submitted for the Adoption of the List of Issues On the Second Periodic Report of Thailand (CCPR/C/THA/2) at the 117th Session of the United Nations Human Rights Committee, 7 April 2016, paras 10, 11
} 


\section{Government policy responses encourage risky journeys}

What each of the above examples show is that Governments' policy responses to the perilous journeys taken by refugees is to focus their attention on denying entry and taking steps to dismantle criminal trafficking and smuggling gangs. These efforts are prone to failure as they ignore the very nature of refugees: people are fleeing their homes because they must; this is not a choice that they make or a weighing up of options. Refugees flee because they have run out of options. Traffickers and smugglers are a product of the demand. When governments foreclose all legal and safe options of flight, refugees will use traffickers and smugglers - because they must. Their activities should be prosecuted and severely punished however there will be new gangs to take their place, to be sure.

The European Union in particular has focused on partnerships with neighbouring transit countries to stem the flow of refugees to Europe. ${ }^{104}$ Whether intended or not, the clear and foreseeable outcome of such policies is a denial of protection to vulnerable refugees, a heightened risk of torture and ill-treatment and a renunciation of the fundamental nonrefoulement obligations. But as Crépeau indicates, "It appears much more "efficient" to do capacity building in transit states so that their authorities will carry out the arrest, detention, and deportation of irregular migrants, and refugee determination procedures if need be. Most of those countries do not have the same democratic culture, the same human rights protection infrastructure, the same active and vocal civil society organisations caring for migrants, the same investigative journalism, or the same independent and competent judiciary.'105 Crépeau explains:

The efficiency argument is twofold. First, most transit States only reluctantly accept to actually create a "refugee and migration problem" for themselves when migrants usually enter and exit the country without much fuss. Turkey has signed an immigration readmission agreement with the EU as a stepping stone to its accession to the EU, but doesn't effectively clamp down on irregular migration unless actively prodded by some EU States. Second, forcing transit States to combat irregular migration means that such migration will be driven underground-or further underground-and that smuggling rings and mafias will control the trade, creating additional law-and-order issues for the authorities, and, in the end, reducing the efficiency of migration controls.

The legal argument is that Global North States are responsible for their actions. If they knowingly empower other States to commit human rights violations against migrants, they should be held accountable for their co-responsibility in such violations. ${ }^{106}$

\section{IV.3 Building Fortresses}

In order to quell the tide of refugees, states have pursued a series of measures - as part of increasingly restrictive migration policies - to prevent refugees and other migrants from entering their territory. These have included imposing restrictive visa regimes and air carrier sanctions, erecting physical barriers at borders, the summary rejection of asylum-seekers at borders or points of entry, creating international zones, creating buffer zones or designating safe areas as well as the maritime interception of asylum seekers and other migrants. ${ }^{107}$ As

\footnotetext{
${ }^{104}$ On 13 May 2015 the European Commission, the EU’s executive body, presented a “European Agenda on Migration” with proposals for a common migration policy

${ }^{105}$ François Crépeau, 'Rejecting Criminalisation and Externalisation: Moving from Enforced Closure to Regulated Mobility' (2015) 104 Geo LJ Online 115, 118

106 Ibid, 118

107 See on the "coercive" system in particular Directorate-General for Internal Policies, Enhancing the Common European Asylum System and Alternatives to Dublin: Study for the Libe Committee, European Parliament, 2015, particularly 18-24 and Thomas
} 
Gammeltoff-Hansen and Hathaway have noted, what they term the policies of non-entree have fuelled the gaps between rich and poor countries, and in many ways have undermined the implementation of collective burden-sharing:

Non-entrée allows wealthier states to insist upon the importance of refugee protection as a matter of international legal obligation, knowing that they will largely be spared its burdens. It enables a pattern of minimalist engagement under which the formal commitment to refugee law can be proclaimed as a matter of principle without risk that the wealthier world will actually be compelled to live up to that regime's burdens and responsibilities to any serious extent. Non-entrée mechanisms have overall proved highly effective: the developed world today protects less than $20 \%$ of the world's refugees and is subject to no binding duty even to share the costs of protection in the less developed world, much less to resettle refugees to their own territories. ${ }^{108}$

But at least some of these deterrent practises may not relieve a state from its responsibilities and may nonetheless result in refoulement. Firstly, states' obligations towards individuals deserving protection do not start only once a state recognises or confirms an individual's status as a refugee. Refugee status is declaratory, and thus the obligations which accrue to refugees, including non-refoulement, applies to any person who meets the refugee definition, irrespective of whether the person concerned has been formally recognised as a refugee, and thus, it includes asylum-seekers whose status has not yet been formally decided. A person does not become a refugee because of recognition, but is recognised because $\mathrm{s} / \mathrm{he}$ is a refugee. Thus, the principle of non-refoulement applies presumptively to persons claiming refugee status but whose claims have not been determined.109 Secondly, and following directly from the first principle, the principle of non-refoulement is understood to encompass the circumstances when a refugee is rejected at the frontier. UNHCR has made clear that '[i]n all cases the fundamental principle of non-refoulement - including non-rejection at the frontier - must be scrupulously observed." 110 Thus, borders should not be closed or impenetrable to prevent the entry of refugees, as this may violate the state's non-refoulement obligations.

The OAU Convention ${ }^{111}$ and Cartagena Declaration ${ }^{112}$ both explicitly link non-refoulement to non-rejection at the frontier. Under human rights law, a state's obligations are engaged as soon as the State can be said to be exercising effective control. In the Hirsi Jamaa case, the European Court of Human Rights recognised that Italy's obligations under the Convention were activated, even in the High Seas.113 This ruling was reinforced by the UN Special Rapporteur on Torture who explained that '[t]he obligations enshrined in the [Torture] Convention also apply to state vessels patrolling or conducting border control operations on the high seas and states' pushbacks of migrants under their jurisdiction can breach the prohibition of torture and illtreatment and non-refoulement obligations'.114 The prohibition of refoulement is complemented by the prohibition of arbitrary expulsion ${ }^{115}$ and of collective expulsion, which equally applies from the moment a state has jurisdiction over a person or a group of persons. ${ }^{116}$

\footnotetext{
Gammeltoft-Hansen and James C. Hathaway, 'Non-Refoulement in a World of Cooperative Deterrence', Columbia Journal of Transnational Law, 53 (2015)235, 244-48

108 Gammeltoft-Hansen and Hathaway, ibid, 242

${ }^{109}$ UNHCR Note on International Protection, UN Doc AJAC.96/694,3 August 1987, para. 23

110 UNHCR Executive Committee Conclusions No. 22 (XXXII) - 1981, II (A) (2)

111 Art II(3)

112 Art III (5)

${ }^{113}$ Hirsi Jamaa v. Italy, ECtHR, App. No. 27765/09 (Grand Chamber), 23 February 2012

${ }^{114}$ UN General Assembly, 'Interim report of the Special Rapporteur on torture and other cruel, inhuman or degrading treatment or punishment' UN Doc A/70/303, 7 August 2015, para 42

115 See in particular article 13 ICCPR and article 1 of Protocol No. 7 ECHR

116 See articles 22(9) of the American Convention on Human Rights, article 12(5) of the African Charter on Human and Peoples' Rights and article 26(1) of the 2004 Arab Charter on Human Rights as well as article 4 of Protocol no. 4 to the European Convention on Human Rights. See also Human Rights Committee, General Comment No.15: The Position of Aliens under the Covenant (1986), para. 10
} 
The US Supreme Court's majority decision in the 1993 Sale vs. Haitian Councils Centre ruling confirmed the legality of the US practice of intercepting and forcibly returning Haitians at sea.117 However this decision was severely criticised by the Inter-American Commission on Human Rights in Haitian Centre for Human Rights $v$ United States, and the approach taken by the Supreme Court was not followed by the European Court of Human Rights in Hirsi Jamaa v Italy or by the UN Committee Against Torture in Marine I, both of which held that states are bound by the prohibition of refoulement from the moment, and as long as, a person comes within the jurisdiction of a state, even if this person is outside the state's physical territory. ${ }^{118}$

\section{IV.3.1 Closing borders and building physical barriers}

The closing of borders to prevent mass influxes of refugees is a practise with a long history. It was used by many states in Europe and further afield to prevent Jews and others fleeing Nazi persecution ${ }^{119}$ and those fleeing fascism in Spain, a situation deemed so unacceptable in hindsight to many states that it was one of the main impetuses for the Refugee Convention.

Some states close borders as an immediate or ad hoc response to what is perceived as a crisis level flow of refugees, because there is insufficient staff to process the entrants and inadequate associated humanitarian resources in place. These may be temporary measures to get the necessary staff in place, or more long-term measures designed to prevent the flows altogether because of the perceived security or resource-driven fears associated with admitting large numbers of foreigners to the country. Sometimes border closures are an attempt by the state to secure greater support from the international community. ${ }^{120}$

In response to recent mass influxes, several states have fortified their borders and use force such as tear gas and rubber bullets when patrolling them to prevent unauthorised entry. Some states, such as Austria, Bulgaria, France, Greece, Hungary, Israel, Macedonia, Spain, Turkey and the USA, have built fences or walls to better control entry and ultimately keep out "irregular migrants" including refugees. ${ }^{121}$

Effectively sealing off borders makes it impossible for states to distinguish between 'irregular' migrants and refugees. States have a right under international law to control the entry of nonnationals into their territory. However, states that turn asylum seekers away at their border or erect walls and fences to avoid giving asylum seekers the opportunity to have their status determined, can breach the prohibition of refoulement. This is further aggravated when states use force to turn back or repel asylum seekers, as has reportedly happened in countries such as Egypt, Spain and the USA.

Border closures and barriers expose asylum seekers and other migrants to an increased risk 'en route' or of injuring themselves or dying when seeking to cross the barriers, as well as to being subjected to the use of force by border patrols. Where they reach borders and have to turn back,

\footnotetext{
${ }^{117}$ Sale v. Haitian Centers Council. Supreme Court of the United States, 509 U.S. 155 (1993)

${ }^{118}$ Haitian Centre for Human Rights v United States, Report No. 51/96, Inter-Am CHR,OEA/Ser.L/V/II.95 Doc. 7 rev. at 550 (1997); Hirsi Jamaa v. Italy, ECtHR, App. No. 27765/09 (Grand Chamber), 23 February 2012; P.K. and others v. Spain, UN Doc

CAT/C/41/D/323/2007, 11 November 2008

${ }^{119}$ Independent Commission of Experts, Switzerland - Second World War: Switzerland, National Socialism, and the Second World War, Final Report (Bergier Report), Pendo Editions, Zurich, 2002

${ }^{120}$ See generally, Katy Long, No entry! A review of UNHCR's response to border closures in situations of mass refugee influx, PDES/2010/07, July 2010

${ }^{121}$ See in particular, Judith Sunderland and Bill Frelick, 'EU's approach to migrants: humanitarian rhetoric, inhuman treatment', OpenDemocracy, 15 April 2015; CoE, Commissioner for Human Rights, Spain: Legislation and practice on immigration and asylum must adhere to human rights standards, 16 January 2015, www.coe.int/en/web/commissioner/-/spain-legislation-and-practice-onimmigration-and-asylum-must-adhere-to-human-rights-standards; and United Nations, UN cites strong concerns over Hungarian border fence plan that could deter refugees and asylum-seekers, 19 June 2015, www.un.org/apps/news/story.asp?NewsID=51201\#.VZQAEFKebrg
} 
refugees and other migrants risk abuse by criminal gangs operating in border areas who prey on the vulnerability of anyone stranded in what is an alien environment. ${ }^{122}$

\section{IV.3.2 'Pushbacks', interdiction on the High Seas and off-shore processing arrangements}

States regularly push back refugees across the border from where they came or indeed prevent them from arriving. Sometimes there is no apparent justification and it is simply a form of collective expulsion or dereliction of responsibility, as was the fate of some Burmese Rohingya, left stranded at sea. Other times, such policies are pursued under the guise that a receiving country is a safe third country; 123 financial assistance is provided to the receiving countries which may be the country of last transit or another country who has simply agreed to the deal, in exchange for taking the human burden of the refugees. This is a further means by which wealthy countries have simply sought to buy themselves out of their obligations to receive and process refugee claims. It undermines the goals of the Refugee Convention and makes a mockery of global burden sharing.

Bilateral and multilateral agreements are central to the implementation of these various forms of extraterritorial deterrence and at the same time have given a gloss of legality to policies which often result in a breach of individuals' fundamental rights. Within the European Union, the Dublin regulation operates so as to prevent refugees from movement within the Union. It requires that the EU Member State where the migrant first enters must assess the individuals' status and where appropriate, to afford protection. Under the regulation, migrants who travel onward to other Member States may be returned to the country of entry, which under the regulation is deemed a safe third country. This regulation has placed a difficult burden on Italy, Greece and Spain who are faced with the bulk of arrivals. The regulation has been upheld by courts but the European Court of Human Rights has determined that due to the specificities of some particular cases, it would violate the applicant's rights to return them to the state through which they first arrived. ${ }^{124}$

Other bilateral and multilateral agreements entered into, with states known for their limited protection of refugee rights and record of non-adherence to the prohibition of torture, are set out below. Many of these agreements contain undertakings that the latter states will respect the rights of persons transferred to them and will not send them to countries where they face a real risk of persecution (refoulement). However, the states predominantly do not have satisfactory systems of refugee status determination in place, some are not party to the relevant Refugee Conventions and sub-standard conditions of detention and the poor treatment of detained asylum seekers and other migrants, including the lack of protection against attacks by fellow detainees and members of the local populations have been well-documented.

The EU has embarked on a diplomatic offensive to establish partnerships with a range of countries under the European Agenda on Migration, listing as priority countries: Afghanistan, Algeria, Bangladesh, Ethiopia, Eritrea, Ghana, Ivory Coast, Mali, Morocco, Niger, Nigeria, Pakistan, Senegal, Somalia, Sudan, and Tunisia. Additional countries identified as short-term priorities are Egypt, Iran, Jordan, Lebanon, Libya, and Morocco.125 The majority of these are major refugee producing countries where torture is routinely practiced.

The EU should be minded to have careful regard to the failings and devastating consequences of the Australian Government's notorious approach of pushbacks and outsourcing, which have

\footnotetext{
${ }^{122}$ Inter-American Commission on Human Rights, Human Rights of Migrants and Other Persons in the Context of Human Mobility In Mexico, OEA/Ser.L/V/II. Doc.48/13, 30 December 2013, 45-118

${ }^{123}$ E.g., Steve Peers, 'The final EU/Turkey refugee deal: a legal assessment' 18 March 2016, available at:

http://eulawanalysis.blogspot.co.uk/2016/03/the-final-euturkey-refugee-deal-legal.html

${ }_{124}$ M.S.S. v. Belgium and Greece (Grand Chamber), Application no. 30696/09, 21 January 2011

${ }^{125}$ See, European Commission, 'Communication on establishing a new Partnership Framework with third countries under the European Agenda on Migration', COM(2016) 385 final, 7 June 2016
} 
resulted in deaths, torture and mistreatment, profound psychological harm as a result of the hopeless situation in which detainees find themselves in, and a derogation of all responsibility for which it has been uniformly condemned. As part of its interdiction at sea policy, Australia has about 20 bilateral arrangements with source countries like Indonesia and Malaysia to suppress smuggling or accept returnees, often in exchange for informal aid projects. Its policy of off-shore detention has come to the fore with the release of over 2,000 leaked reports to the Guardian newspaper. ${ }^{126}$ But reports of devastating abuses have been well-known for years, with little appreciable impact on the reform of policies. A report by the Australian Senate Legal and Constitutional Affairs References Committee into certain incidents at the Manus Island Detention Centre in February 2014 found that a policy of prolonged and potentially indefinite periods of detention and of encouraging asylum seekers to return home, instead of continuing to live in a state of limbo, may also amount to constructive (de facto) refoulement by making living conditions so intolerable that the asylum seekers agree to leave "voluntarily". ${ }^{127}$ The Committee found that the events which included rioting and deaths were foreseeable, and may have been prevented if transferees had been given a clear pathway for the assessment of their asylum claims. ${ }^{128}$ It also determined that the Australian Government was responsible for failing to protect asylum seekers from excessive use of force. ${ }^{129}$ It determined that the degree of involvement by the Australian Government in the establishment, use, operation, and provision of total funding for the centre clearly satisfies the test of effective control in international law, and the government's ongoing refusal to concede this point displays a denial of Australia's international obligations.'130

A number of allegations of sexual assaults, including rape, by fellow detainees and by members of staff, as well as other incidents, prompted an official review in October 2014 'into recent allegations relating to conditions and circumstances' at the Nauru RPC (also referred to as the Moss report). ${ }^{131}$ The review 'became aware of allegations of indecent assault, sexual harassment and physical assault occurring in the Centre', and, after noting that some of them 'had not been formally reported', concluded 'that there is a level of under-reporting of transferees of sexual and other physical assault.'132 It further concluded that 'many transferees are apprehensive about their personal safety and have concerns about their privacy in the Centre... The perception of a lack of personal safety and privacy is heightened by high density accommodation in mostly un-aired-conditioned, soft-walled marquees in a tropical climate.'133 The review found a number of structural shortcomings, including inadequate arrangements for complaints mechanisms, lack of adequate training, and the need for a clearer relationship between privatised service providers and the Nauruan Police Force.134 The Australian National Human Rights Commission also raised a number of concerns, particularly about the treatment of children and the inadequacy of pre-transfer assessments. ${ }^{135}$

Bilateral and multilateral agreements entered into, with states known for their limited protection of refugee rights and record of non-adherence to the prohibition of torture:136

\footnotetext{
${ }^{126}$ Paul Farrell, Nick Evershed and Helen Davidson, 'The Nauru Files: cache of 2,000 leaked reports reveal scale of abuse of children in Australian offshore detention', The Guardian, 10 August 2016

127 The Senate, Legal and Constitutional Affairs References Committee, Incident at the Manus Island Detention Centre from 16

February to 18 February 2014, 11 December 2014, 72 (Manus Island Inquiry)

128 Ibid

129 Ibid, 146

130 The Senate, Legal and Constitutional Affairs References Committee, Incident at the Manus Island Detention Centre from 16

February to 18 February 2014, 11 December 2014, 151, 8.33

131 Philip Moss, Review into recent allegations relating to conditions and circumstances at the Regional Processing Centre in Nauru,

Final Report, 6 February 2015 (Moss Report)

132 Ibid., 9,16

133 Ibid., 12

134 Ibid., passim

135 Australian Human Rights Commission, The Forgotten Children, National Inquiry into Children in Immigration Detention (2014), 56,

according to which, in September 2014, children were held in detention one year and two months on average (emphasis added)

136 See generally, Gammeltoft-Hansen and Hathaway (n. 107), who set out the framework used below.
} 
(i) Providing funding to transit or other third countries for migration control and/or off-shore processing purposes, such as the United States to Mexico, Spain to Morocco and Italy to Libya. This is the essence of the European Agenda on Migration, as explained above. ${ }^{137}$ The EU has funded states such as Turkey and Ukraine to strengthen border controls and build immigration detention facilities. ${ }^{138}$ The ostensible purpose of this policy is to prevent asylum seekers and other migrants from reaching the territories of EU Member States by land through key transit countries. The policy and underlying agreements have been criticised, also on account of a series of reports on poor detention conditions and ill-treatment of refugees in both Turkey and the Ukraine. ${ }^{139}$ Australia has provided funding to Sri Lanka to advance its non-entry policy. ${ }^{140}$ Australia has also rendered the application of mainland protection procedures inapplicable to asylum seekers who arrive by boat in particularly designated "excised offshore places", and transferred asylum seekers to Pacific Islands such as Christmas Island, Papua New Guinea, Manus or Nauru for so-called offshore processing, detention, settlement or sent to a safe third country, such as Cambodia, ${ }^{141}$ and it has funded and overseen these operations. ${ }^{142}$

(ii) Providing equipment, machinery, and training or extraneous funding such as aid or debt relief to the cooperating state, for example Italy to Libya, USA to Mexico, Spain to Morocco and Australia to Sri Lanka. Australia funded and closely cooperated with the International Organisation for Migration to build and maintain immigrant detention facilities in Indonesia. ${ }^{143}$ Australia pursued this policy notwithstanding public knowledge about poor conditions of detention and illtreatment in Indonesia's immigration detention centres. ${ }^{144}$ Australia provided patrol boats to Sri Lanka in 2013, which has reportedly preventing individuals from leaving their own country ${ }^{145}$ and enhanced the risk of torture of anyone attempting to flee that is intercepted by Sri Lankan officials, documented in several instances. ${ }^{146}$

(iii) Deploying or seconding officials from the destination state to cooperate with officials in other states (origin, transit), such as US officials to states in Central America and Mexico, and other regions of the world.

\footnotetext{
${ }^{137}$ See, European Commission, 'Communication on establishing a new Partnership Framework with third countries under the European Agenda on Migration', COM(2016) 385 final, 7 June 2016

${ }^{138}$ Esra S. Kaytaz, 'At the border of "Fortress Europe": Immigration Detention in Turkey', in Amy Nethery and Stephanie J. Silverman (eds), Immigration Detention: The migration of a policy and its human impact (Routledge, 2015), 59-68, 60, which refers to the Twinning Project (2009-2011), "Support to Turkey's Capacity in Combating Illegal Migration and Establishment of Removal Centres for Illegal Migrants", which "provided for the construction of removal centres in the cities of Ankara and Erzurum with financial support from the European Commission'; Maximillian Pop, 'Guantanamo of the East: Ukraine locks up refugees at the EU's behest', Spiegel Online International, 17 February 2015, www.spiegel.de/international/europe/ukraine-receives-eu-funds-to-block-asylumseekers-from-reaching-europe-a-1018907.html

${ }^{139}$ Report by the Special Rapporteur on the human rights of migrants, François Crépeau, Addendum: Mission to Turkey (25-29 June 2012), UN Doc A/HRC/23/46/Add.2, 17 April 2013, paras. 40-58; Committee against Torture: Concluding observations: Turkey, UN Doc CAT/C/TUR/CO/3, 20 January 2011, para. 15; Human Rights Watch, Buffeted in the Borderland: The treatment of asylum seekers and migrants in Ukraine, 16 December 2010

${ }^{140}$ See concerns in Report by the Special Rapporteur on the human rights of migrants, François Crépeau, Addendum: Mission to Sri Lanka, UN Doc A/HRC/29/36/Add.1, 2 April 2015, para. 70

${ }^{141}$ Memorandum of Understanding between the Government of the Kingdom of Cambodia and the Government of Australia relating to the Settlement of Refugees (MOU), 26 September 2014

${ }^{142}$ Report of the Special Rapporteur on torture and other cruel, inhuman or degrading treatment or punishment, Manfred Nowak, on his mission to Papua New Guinea (14-25 May 2010), UN Doc A/HRC/16/52/Add.5, 7 February 2011; Report of the Working Group on the Universal Periodic Review: Nauru, A/HRC/17/3, 8 March 2011

${ }^{143}$ Amy Nethery and Stephanie J. Silverman (eds), Immigration Detention: The migration of a policy and its human impact (Routledge 2015)

${ }^{144}$ Amy Nethery, Brynna Rafferty-Brown and Savitri Taylor, 'At the discretion of management: immigration detention in Indonesia', in Nethery andSilverman, ibid, 114-124, at 117-120

${ }^{145}$ Human Rights Law Centre, Can't Flee, Can't Stay: Australia's interception and return of Sri Lankan asylum seekers, March 2014, http://www.hrlc.org.au/wp-content/uploads/2014/03/HRLC_SriLanka_Report_11March2014 ${ }^{146} \mathrm{Ibid}$
} 
(iv) "Joint or shared enforcement", such as by the US Government with Mexican authorities, Australia with Sri Lanka, and Spain with Senegal and Mauritania.

(v) Measures taken by authorities on the territory of the state of origin or transit, such as European states operating in the waters of Libya, Mauritania and Senegal.

(vi) Use of international agencies to carry out joint deterrent action in the name of multiple states, such as the European Agency for the Management of Operational Cooperation at the External Borders of the Member States of the European Union (Frontex). ${ }^{147}$ Frontex has provided support to European Member States, such as Greece, including by assisting in the detention of migrants, notwithstanding the woefully inadequate conditions of detention and heightened risks of ill-treatment. ${ }^{148}$

As already indicated, states' responsibilities apply extraterritorially to the extent that the persons are under the effective control of that state. ${ }^{149}$ This has been made clear in the Hirsi case in relation to states' responsibilities on the High Seas; it has also been made clear by the UN Special Rapporteur on Torture, who has indicated that '[r]efoulement may implicate extraterritorial State conduct whenever States operate and hold individuals abroad, as in the context of armed conflict or offshore detention or refugee processing facilities.' ${ }^{150}$ Furthermore, what is also clear is that states cannot avoid their international obligations by using or hiring other states or private actors to exercise their governmental activity. 151 This is without prejudice to the receiving states' own responsibility for the violations of the human rights of refugees and the potential contractual, criminal and tort liability of private service providers who often implement on behalf of the various governments.

Given the nature of push-backs and other deterrence strategies, once the refugees have been returned or sent to a third country, it will be difficult if not impossible for them to pursue effective complaints and remedies against an offending state or other responsible actor, regardless of their responsibility under domestic or international law. The would-be complainants will typically not have access to lawyers in the offending state and their situation of vulnerability and utter destination makes such legal remedies illusory in all but a small few cases. In the absence of safeguards, monitoring and effective complaints procedures concerning these deterrence strategies, it is difficult to establish the extent of the practice of ill-treatment in such contexts, which perpetuates the prevailing lack of transparency and impunity.

\section{IV.4 The destination country}

'I slept that night in Brixton, at the tube station. An old man who was drinking told me the Home office was in Croydon and that I needed to get another bus. I gave him some money to buy a ticket, but he took the money and didn't give me the ticket. A bus driver told me he would tell me where the Home Office was. When I got there it was Friday and it was closed. I stayed there Friday, Saturday, Sunday. I didn't eat because my money was finished. I just went and sat in one corner and cried, thinking maybe I should throw myself in front of a car, it's the end of my life. I asked some people when the Home Office was open, they said things like 'Shut up' and 'Fuck off.' On Monday I went back there very early in the morning. I saw a lot of people standing there. I saw some black people so I thought 'Maybe I should ask these ones'. That's how I went to Home Office.'152

\footnotetext{
147 Gammeltoft-Hansen and Hathaway (n. 107), 248-57

148 Human Rights Watch, The EU's Dirty Hands: Frontex involvement in ill treatment of migrant detainees in Greece (2011)

${ }^{149}$ Lauterpacht and Bethlehem (n. 53), paras 67

150 UN General Assembly, 'Interim report of the Special Rapporteur on torture and other cruel, inhuman or degrading treatment or punishment' UN Doc A/70/303, 7 August 2015, para 38

151 Lauterpacht and Bethlehem (n. 53), paras 61

152 Ugandan torture survivor and former child soldier. REDRESS, Torture: Stories of Survival, June 2005, 25
} 
By the time they reach their final destination, refugees are likely to be physically and emotionally exhausted, confused and disoriented. They will have built up all sorts of expectations about the destination, which have kept them motivated, and moving, towards their ultimate goal. Rarely will what they find on arrival meet those expectations.

\section{IV.4.1 Refugee claims determination}

... the shortcomings in access to the asylum procedure and in the examination of applications for asylum ...: insufficient information for asylum-seekers about the procedures to be followed; difficult access to the Attica police headquarters; no reliable system of communication between the authorities and the asylum-seekers; a shortage of interpreters and lack of training of the staff responsible for conducting the individual interviews; a lack of legal aid effectively depriving the asylum-seekers of legal counsel; and excessively lengthy delays in receiving a decision. These shortcomings affect asylum-seekers arriving in Greece for the first time as well as those sent back there in application of the Dublin Regulation. The Court is also concerned... that almost all firstinstance decisions are negative and drafted in a stereotyped manner without any details of the reasons for the decisions being given ...

The Court concludes that to date the Greek authorities have not taken any steps to communicate with the applicant or reached any decision in his case, offering him no real and adequate opportunity to defend his application for asylum. What is more, the Court takes note of the extremely low rate of asylum or subsidiary protection granted by the Greek authorities compared with other European Union member States .... The importance to be attached to statistics varies, of course, according to the circumstances, but in the Court's view they tend here to strengthen the applicant's argument concerning his loss of faith in the asylum procedure.

... the Court finds that there has been a violation of Article 13 of the Convention taken in conjunction with Article 3 because of the deficiencies in the Greek authorities' examination of the applicant's asylum request and the risk he faces of being returned directly or indirectly to his country of origin without any serious examination of the merits of his asylum application and without having access to an effective remedy. ${ }^{153}$

The Refugee Convention makes clear that persons who have a legitimate fear of persecution on the basis of one of the enumerated grounds in the Convention should be recognised as refugees, barring the exclusion provisions already present in the Convention. There will normally be a claims procedure in the destination country which assesses the applicant's claims for refugee status.

However, few countries have put in place fair and efficient refugee claims determination procedures that are child and gender-sensitive, and capable of adequately determining claims and preventing refoulement. In many regions, mass influxes in which there is an arrival of large numbers of applicants who may have no valid claim to protection at the same time as the arrival of masses of persons with valid refugee claims can complicate and in some instances jeopardize the effectiveness of national procedures for the determination of refugee status.

But most importantly, policies of deterrence tend to infect claims determination procedures.

${ }_{153}$ M.S.S. v. Belgium and Greece (Grand Chamber), Appl no. 30696/09, 21 January 2011, paras 301-2, 313, 321 
Australian authorities conducted refugee status determinations of the passengers from the ACV Triton by satellite phone as part of the Australian Government's 'enhanced screening' process. This process involves asking each of the asylum seekers a set of four questions and determining their refugee status on the basis of their answers to these questions (the asylum seeker's name, country of origin, where they had come from, and why they had left) without a right to appeal a negative decision. Some passengers reported that they could not understand the immigration officials with whom they were speaking, or hear them properly over the sound of machinery on the open deck of the ship. One asylum seeker estimated that the satellite phone dropped out between ten and fifteen times during the interview which lasted 30 to 45 minutes. Several passengers also stated that they did not feel they could speak freely to immigration officials because their interviews were conducted in front of other passengers. Forty passengers had their asylum claims rejected. One Sinhalese passenger was assessed as being eligible for further assessment. He elected to return to Sri Lanka with the other passengers when informed that he would be transferred to Manus Island, Papua New Guinea or Nauru and be placed in immigration detention pending his refugee status determination. (footnotes omitted) ${ }^{154}$

Restrictive claims processing procedures are often aimed at expediting status determination and removal. 'Fast track' procedures can reduce procedural fairness for applicants and increase prospects for detention despite vulnerability, which in turn increases the likelihood of torture and ill-treatment, and will make worse the trauma and suffering of those who have escaped intense violence. Truncated procedures also limit the possibility for the asylum seeker to put forward their own narrative of why they have a genuine fear of persecution and to present the relevant evidence to substantiate their claims. As explained by Vogl, 'Those who cannot tell their stories quickly or provide evidence fast enough will fail in their applications for protection.' ${ }^{155}$

Asylum seekers should have a personal interview and be provided with legal assistance, and procedures should be in place to identify and assist vulnerable asylum seekers. Yet, unclear legislative frameworks, arbitrary decision-making, as well as limited access to the necessary information and legal assistance to pursue their claims are at the heart of procedures that frequently result in the rejection of applications. The Inter-American Court of Human Rights has stressed the importance of guarding against arbitrariness. In the case of the Pacheco Tineo Family v. Bolivia, which concerned Bolivia's treatment of a family of asylum seekers from Peru, the Court underscored that in application of the principles of non-discrimination and due process [states] must ensure predictable proceedings, as well as coherence and objectivity in decision-making at each stage of the proceedings to avoid arbitrary decisions.'156

\section{UNHCR has stressed that}

'[i]n most cases a person fleeing from persecution will have arrived with the barest necessities and very frequently even without personal documents. Thus, while the burden of proof in principle rests on the applicant, the duty to ascertain and evaluate all the relevant facts is shared between the applicant and the examiner. Indeed, in some cases, it may be for the examiner to use all the means at his disposal to produce the necessary evidence in support of the application. Even such independent research may not, however, always be successful and there may also be statements that are not

\footnotetext{
${ }^{154}$ Andreas Schloenhardt and Colin Craig, “'Turning Back the Boats”: Australia’s Interdiction of Irregular Migrants at Sea', (2015) 27(4) International Journal of Refugee Law 536, 554-5

${ }^{155} \mathrm{~A}$ Vogl, 'A Matter of Time: Enacting the Exclusion of Onshore Refugee Applicants through the reform and Acceleration of Refugee Determination Processes', (2016) 6(1) Oñati Socio-legal Series 137, 141

${ }^{156}$ Case of the Pacheco Tineo Family v. Bolivia (Preliminary objections, merits, reparations and costs), Series C No. 272, 25 November 2013, para 157. The Court enumerates a list of procedural safeguards that states must comply with, at para. 159.
} 
susceptible of proof. In such cases, if the applicant's account appears credible, he should, unless there are good reasons to the contrary, be given the benefit of the doubt. 157

The UN Committee Against Torture has underscored that states cannot sit back and wait for vulnerable claimants to put forward incontrovertible proof which they will never be able to access; once a claimant makes a prima facie case, the state is obligated to make sufficient efforts to determine whether there are substantial grounds for believing that the author would be in danger of being subjected to torture. ${ }^{158}$

Despite this, many states place administrative and logistical hurdles in front of claimants and often states place undue evidential burdens or misapply the terms of the Refugee Convention. Some states use inferences when assessing the credibility of claims, such as the failure to submit an asylum request within a certain time limit or the inability to recall certain details. Such approaches ignore the impact that trauma has been found to have on refugees' ability to recall with clarity their experiences, ${ }^{159}$ and may result in a majority of claims being denied. The UN Committee Against Torture has held that complete accuracy could not be expected by victims of torture, especially those suffering from post-traumatic stress syndrome, as long as any inconsistencies were of an immaterial nature and did not raise doubts about the general veracity of the author's claims. ${ }^{160}$ The UNHCR guidelines indicate that the applicant must be able to demonstrate 'good reasons' for the fear of persecution which must be well-founded. ${ }^{161}$ But what is clear is that the criteria and standards of proof for determining whether an applicant has a well-founded fear of persecution is applied differently from one state to another, often leading to vastly differing results. ${ }^{162}$ In some countries such as Israel ${ }^{163}$ and Japan, the acceptance rate for claims is less than $1 \%$.

When an individual faces a risk of torture or other prohibited ill-treatment, states are obligated to take into account the standards that apply to the non-refoulement to torture provisions set out in many human rights treaties. In Aemei v. Switzerland, the UN Committee Against Torture made clear that the author's expulsion to Iran would have the 'foreseeable consequence of exposing him to a real and personal risk of being arrested and tortured.'164

In some countries, the 'bad faith' of an asylum seeker has been used as a basis to deny refugee status, even though the requirement of 'good faith' is not present in the Convention which focuses simply on determining whether there is a credible risk of persecution. ${ }^{165}$ Bad faith has been said to exist for instance, when an asylum applicant manufactures a risk of harm in the home country which did not previously exist. This approach has been rejected by some UK courts. 166

Rejected asylum seekers should be able to challenge any adverse decisions made and should be permitted to remain in the country while the appeal is being determined. Unsuccessful

\footnotetext{
${ }^{157}$ UNHCR, 'Handbook and Guidelines on Procedures and Criteria for Determining Refugee Status under the 1951 Convention and the 1967 Protocol relating to the Status of Refugees', Reissued, Geneva, December 2011, HCR/1P/4/ENG/REV. 3, para 196 ${ }^{158}$ A.S. v. Sweden, Comm. No. 149/1999, 15 February 2001, para. 8.6. See also, F.K. v. Denmark, Comm. No. 580/2014, 9 February 2016, para. 7.6

159 See e.g., Maureen E. Cummins, 'Post-Traumatic Stress Disorder and Asylum: Why Procedural Safeguards Are Necessary', (2013) 29 J. Contemp. Health L. \& Pol'y 283, 288

160 Pauline Muzonzo Paku Kisoki v Sweden (8 May 1996), Comm No. 41/1996, CAT/C/16/D/41/1996, para.9.3

161 UNHCR, Handbook and Guidelines on Procedures and Criteria for Determining Refugee Status under the 1951 Convention and the 1967 Protocol Relating to the Status of Refugees, HCR/1P/4/ENG/REV. 3 December 2011

162 The different approaches of certain states is discussed in R. v. Secretary of State for the Home Department, ex parte Adan, R. v. Secretary of State for the Home Department, ex parte Aitseguer [2001] 1 All E.R. 593

163 Zhanna Veyts, 'A Reprieve for Eritrean Asylum Seeker in Israel', 6 February 2015, http://www.hias.org/blog/reprieve-eritreanasylum-seeker-israel

${ }^{164}$ Aemei v. Switzerland, UNCAT, Comm. No. 34/1995, 29 May 1997, para. 9.5

${ }^{165}$ Refugee Appeal No 2254/94 Re HB, New Zealand Refugee Status Appeals Authority, 21 September 1994; Somaghi v Minister for Immigration, Local Government and Ethnic Affairs [1991] FCA 389

166 Danian v Secretary for the Home Department [1999] EWCA Civ 3000
} 
applicants should be enabled to have a negative decision reviewed before rejection at the frontier or forcible removal from the territory. However often, there is a lack of effective remedies to challenge the denial of refugee status. And, persons are being removed before their non-refoulement claims have been resolutely determined, whether at the domestic level, pending appeals or when there are pending procedures before regional or international claims processes.

\section{IV.4.2 Immigration detention}

Immigration detention deprives persons of their liberty even though they have not committed any crime. It also frequently exposes asylum seekers and other migrants to an enhanced risk of torture or other ill-treatment. It can also contribute to the deterioration of detainees' mental health, ${ }^{167}$ as well as add a further layer of bewilderment, frustration and helplessness. ${ }^{168}$ Many asylum seekers are survivors of torture. As torture often takes place in a detention setting, detaining torture victims can trigger traumatic reactions. ${ }^{169}$

Such detention is incompatible with human rights law unless stringent conditions are met. The detention cannot be arbitrary; 170 it cannot be based solely on the fact that someone has entered a country to seek asylum; ${ }^{171}$ it must not be indeterminate ${ }^{172}$ and it must be subject to judicial control and other safeguards. ${ }^{173}$ The decision to detain must consider the individual circumstances of the person(s) concerned. As a rule, particularly vulnerable persons including unaccompanied minors ${ }^{174}$ and others should not be detained.175 The EU Recast Reception Conditions Directive and the EU Return Directive list survivors of 'torture, rape or other serious forms of psychological, physical or sexual violence' under the category of vulnerable persons requiring special attention. ${ }^{176}$ The Directives do not prohibit detention of vulnerable persons but instead stipulate a duty to monitor and provide adequate support and health services. ${ }^{177}$ This approach is insufficient in that it does not address the link between the detention itself and re-traumatisation. Also it ignores the numerous examples of states' failure to provide adequate support and health services. ${ }^{178}$ Detention should 'only be resorted to when it is determined to be necessary, reasonable in all the circumstances and proportionate to a legitimate purpose.'179 Protection of public order, public health and national security are recognised as legitimate purposes. In contrast, punitive considerations, deterrence or administrative convenience are

\footnotetext{
167 Tania Storm \& Marianne Engberg, 'The impact of immigration detention on the mental health of torture survivors is poorly documented- a systematic review' Danish Medical Journal 60/11 (November 2013), 4-5

168 See in particular Mary Bosworth, Inside Immigration Detention (Oxford University Press, 2014)

169 Natasha Tsangarides, 'The Second Torture: The Immigration Detention of Torture Survivors', Summary Report', Medical Justice, May 2012, 3

170 UNHCR, Detention Guidelines: Guidelines on the applicable criteria and standards relating to the detention of asylum seekers and alternatives to detention (2012), Guideline 4.1

${ }^{171}$ Article 31 of the Refugee Convention. This is also recognised in recently adopted EU instruments, see article 26(1) of the Asylum Procedures Directive (2013/32/EU), articles 8(1) of the recast Receptions Conditions Directive (2013/33/EU), and article 28(1) of the recast Dublin regulation (EU/604/2013)

172 Suso Musa v. Malta, Appl no. 42337/12, 23 July 2013 and Lokpo et Touré v. Hungary, Appl no. 10816/10, 20 September 2011 173 UNHCR, Detention Guidelines (n. 170); CPT Standards of Detention, Rev. 2011, Chapter IV: Immigration Detention, CPT/Inf/E (2002) 1. See also Inter-American Commission on Human Rights, Report on Immigration in the United States: Detention and Due Process, OEA/SEr.L/V/II. Doc. 78/10, 30 December 2010, paras. 32-93. See also, Izabella Majcher, "Crimmigration" in the European Union through the Lens of Immigration Detention, Global Detention Project Working Paper No. 6, September 2013

${ }^{174}$ Committee on the Rights of the Child, General Comment No. 6: Treatment of Unaccompanied and Separate Children Outside their Country of Origin, UN Doc CRC/GC/2005/6 (2005), para. 61. See also Inter-American Court of Human Rights, Rights and guarantees of children in the context of migration and/or in need of international protection, Advisory Opinion (2014)

175 UNHCR, Detention Guidelines (n. 170), Guideline 9.1.; Human Rights Committee, General Comment no. 35, para. 18; OHCHR, Trauma of torture victims should not be overlooked amid migration challenges, UN experts remind States, 24 June 2015, www.ohchr.org/EN/NewsEvents/Pages/DisplayNews.aspx?NewsID=16135\&LangID=E\#sthash.izCGudIM.dpuf 176 Article 11 (1) of Directive 2013/33; Article 16 (3) of Directive 2008/112/EC

177 See articles 11 (1) of Directive 2013/33. Article 16(3) of Directive 2008/112 is more limited as it does not stipulate a duty to regularly monitor the health of vulnerable detainees.

178 IRCT, Recognising Victims of Torture in National Asylum Procedures: A comparative overview of early identification of victims and their access to medico-legal reports in asylum-receiving countries, 2013

179 UNHCR, Detention Guidelines (n. 170), Guideline 4.2
} 
not. ${ }^{180}$ Asylum seekers should not be detained together with suspected or convicted criminals. ${ }^{181}$

\section{Who is detained?}

Frequent resort to immigration detention is a product of the tendency to criminalise the asylum seeking process, explained in earlier sections. The Global Detention Project has reported that nearly 60 detention centres have been used in Egypt to house migrants, including victims of trafficking, refugees and others. ${ }^{182}$ In some countries, prolonged and sometimes indefinite immigration detention has also been used as a tactic to remove unwanted migrants from sight, to inhibit access to information, to counsel, to translators, to expedite processing of dubious claims and removals, and to deter future migrants. In Australia, any person who arrives by sea without a visa is automatically detained as an 'unlawful' migrant.183

UNHCR makes clear in its guidelines that vulnerable people should not be detained. In practise however, they often are. Indonesia, for example, has been condemned for detaining child migrants, ${ }^{184}$ as has Australia ${ }^{185}$ and Greece. ${ }^{186}$ In the European context, only a minority of states have put procedures in place to screen refugees to identify torture survivors and make arrangements for alternatives to detention, ${ }^{187}$ and the procedures where they are in place lack clarity and are not applied uniformly. In the UK, torture survivors should be identified during the screening interview prior to any detention or at the beginning of a period, or during detention. Rule 35 of the Detention Centre Rules of 2001 is meant to act as a safeguard for vulnerable individuals whose detention would be inappropriate. It requires medical practitioners in detention centres to report to the centre manager any cases in which there are: (1) concerns that continued detention may be injurious to the detainee's health; (2) concerns that the detainee may be a suicide risk; or (3) may have been a victim of torture. ${ }^{188}$ However, the High Court found that Rule 35 reports 'are not the effective safeguard they are supposed to be' and do not in fact work to remove unsuitable cases from detention. ${ }^{189} \mathrm{~A}$ Home Office audit found that only nine percent of Rule 35 reports led to release. ${ }^{190}$ In one particularly egregious case, Alois Dvorzac, an 84 year old man suffering from Alzheimer's who died in handcuffs while detained, had reportedly been the subject of a Rule 35 report stating that he was unfit for detention. ${ }^{191}$ Similar problems have been encountered in other countries with large numbers of asylum seekers. In the USA, screening is not uniformly in place, ${ }^{192}$ and the practice lacks transparency and consistency. ${ }^{193}$ Similar criticisms have been levelled against Australia. ${ }^{194}$

\footnotetext{
${ }^{180}$ UNHCR, Detention Guidelines (n. 170), Guideline 4.1

${ }^{181}$ General Comment 35, para. 18

182 https://www.globaldetentionproject.org/countries/africa/egypt

${ }^{183}$ Australian Government Department of Immigration and Citizenship (DIAC), Managing the Border: Immigration Compliance,

2004-2005 Edition, 2006, p. 5, available at http://www.immi.gov.au/media/publications/compliance/managing-theborder/index.htm

${ }^{184}$ Committee on the Rights of the Child, Concluding observations on the combined third and fourth periodic reports of Indonesia, UN Doc CRC/C/IDN/CO/3-4, 10 July 2014; Human Rights Watch, 'Barely Surviving: Detention, Abuse, Neglect of Migrant Children in Indonesia,' 24 June 2013

185 Report of the Special Rapporteur on torture and other cruel, inhuman or degrading treatment or punishment, Juan E. Méndez, UN Doc A/HRC/28/68/Add.1, 6 March 2015, para 19

${ }^{186}$ HRW, 'Why Are You Keeping Me Here?” Unaccompanied Children Detained in Greece', September 2016

${ }^{187}$ See European Migration Network, The use of detention and alternatives to detention in the context of immigration policies -

Synthesis Report for the EMN Focussed Study 2014 (2014), 21. See IRCT, Recognising Victims of Torture in National Asylum

Procedures: A comparative overview of early identification of victims and their access to medico-legal reports in asylum-receiving countries, 2013, for a worldwide overview.

188 Government Guidelines on Detention Rule 35 Process,

https://www.gov.uk/government/uploads/system/uploads/attachment data/file/257437/rule35reports.pdf

189 Detention Action v. Secretary of State for the Home Department [2014] EWHC 2245 (Admin), cited at Detention Action, "The State of Detention: Immigration Detention in the UK in 2014' (October 2014), 22

${ }^{190}$ Home Office, Detention Centre Rule 35 Audit, February 2011, www.medicaljustice.org.uk/images/stories/reports/r35auditukba.pdf

${ }^{191}$ Colin Yeo, 'Deaths in detention, Home Office legal duties and Rule 35', 31 March 2014, www.freemovement.org.uk/deaths-indetention-home-office-legal-duties-and-rule-35/

${ }^{192}$ IRCT, Recognising Victims of Torture in National Asylum Procedures: A comparative overview of early identification of victims and their access to medico-legal reports in asylum-receiving countries, 2013, 53

193 Ibid
} 
Sometimes a receiving country will put in place special detention rules for persons coming from a particular country or understood to pose a particularly security threat. Israel, for example, was effectively keeping Sudanese asylum seekers who were perceived as a security threat, in indefinite detention. ${ }^{195}$ Israel's Supreme Court found that the law which sought to provide a legal basis for the detention of asylum seekers coming from countries "hostile" to Israel violated the right to liberty. ${ }^{196}$ In response, Israel enacted Amendment No.4, which provided for the indefinite detention of Sudanese and Eritrean asylum seekers in the "Holot", i.e. a desert camp. Amendment No.4 was again successfully challenged, with the Supreme Court annulling its detention provisions in September 2014. ${ }^{197}$ Asylum-seekers detained in Holot are now offered to leave Israel for an unnamed third country [understood to be Rwanda or Uganda]. If they refuse to do so, after 30 days, they would be incarcerated in Saharonim prison. 198 It also discriminates against asylum seekers on the basis of their origin, declaring that they come from a hostile country when it is this very country whose hostility forced them to leave.

\section{For how long?}

The UN Human Rights Committee found that a four year period of detention of an asylum seeker on the ground that he had entered Australia illegally and may abscond if left at liberty was disproportionate and arbitrary. ${ }^{199}$ The detention of an Iranian asylum seeker who had developed mental health problems for over two years 'without individual justification and without any chance of substantive judicial review' was also considered by the Committee to be arbitrary. ${ }^{200}$ It also found arbitrary the practice of mandatory detention upon arrival coupled with adverse security assessments, where 'the authors ... are not informed of the specific risk attributed to each of them and of the efforts undertaken by the Australian authorities to find solutions which would allow them to obtain their liberty. They are also deprived of legal safeguards allowing them to challenge their indefinite detention.'201

Arbitrary, potentially indefinite, detention has also been held to violate the prohibition of torture and ill-treatment. In F.K.A.G. et al. $v$ Australia, counsel had informed the Human Rights Committee about the 'escalating risk to the mental and physical health of the authors in detention', including attempted self-harm and suicide. ${ }^{202}$ Indefinite detention of asylum seekers without any clear procedure and prospect for release is inherently incompatible with the prohibition of torture and ill-treatment where the detention contributed to the deterioration of the applicant's mental health. ${ }^{203}$ This jurisprudence is echoed by Australia's Human Rights Commission in a case concerning the detention of an asylum seeker for 33 months. ${ }^{204}$

\footnotetext{
194 Ibid

195 See Yonatan Berman and Reuven (Ruvi) Ziegler, 'The union of securitisation and demography: Immigration Detention in Israel', in Nethery and Silverman (n. 143), 154-62, at 159-60

${ }^{196}$ HCJ 7146/12, Adam et al. v. The Knesset et al. (judgment of 16 September 2013), as cited, ibid, 162

197 HCJ 8425/13 Anonymous v. The Knesset et al. (22 September 2014), as cited ibid

198 The Hotline for Refugees and Migrants, 'I Believed Israel that I Will Find Shelter in Uganda', 14 June 2015

http://hotline.org.il/en/i-believed-israel-that-i-will-find-shelter-in-uganda

${ }_{199}$ A. v. Australia, UN Doc CCPR/C/59/D/560/1993 (30 April 1997), para. 9.4

${ }^{200} C$ v. Australia, UN Doc CCPR/C/76/D/900/1999 (28 October 2002), para. 8.2

201 F.K.A.G. et al. v. Australia, UN Doc CCPR/C/108/D/2094/2011 (28 October 2013), para 9.4 and M.M.M. et al. v. Australia, UN Doc CCPR/C/108/D/2136/2012 (28 October 2013), para. 10.4. See also, Concluding observations of the Committee on the Elimination of Racial Discrimination: Australia, UN Doc. CERD/C/AUS/CO/15-17, 13 September 2010, para.24; CRC, Concluding observations: Australia, UN Doc CRC/C/AUS/CO/4, 28 August 2012, para. 80 Committee against Torture, Concluding observations on the combined fourth and fifth periodic reports of Australia, UN Doc. CAT/C/AUS/CO/4-5, 23 December 2014, para. 16

${ }^{202}$ F.K.A.G. v. Australia, para.2.7. The European Court of Human Rights has concluded similarly in Yarashonen v Turkey, Appl No. 72710/11, 24 June 2014, para. 80

${ }^{203}$ C. v. Australia, para. 8.4

${ }^{204}$ Ince v. Commonwealth of Australia (Department of Immigration and Citizenship), Report into arbitrary detention, the right to be treated with humanity and with respect for the inherent dignity of the human person and the right to be free from arbitrary interference with the family, [2013] AusHRC 62, para. 5. See similar wording in paras.71, 98 (c) and 118
} 


\section{Torture and ill-treatment in Detention}

Torture and ill-treatment of migrants is a pernicious problem in many transit countries where individuals are detained, but also in destination countries. ${ }^{205}$ It is committed by those officials who guard the facilities; sometimes these are state officials but increasingly they are individuals paid by private security companies contracted by the state. In South Africa, for example, unqualified staff employed by the company G4S reportedly forcibly injected dozens of detainees with anti-psychotic medication and used electric shocks to subdue them, in addition to holding detainees in isolation cells for up to three years. ${ }^{206}$

Excessive force has been used as a disciplining and restraining tool and a means to quell protests. ${ }^{207}$ Allegations of sexual violence are widespread. Male personnel employed by Serco in Yarl's Wood, United Kingdom, for example, are alleged to have looked at women taking showers, using routine checks as pretext, offered favours in exchange for sexual services, and adopted a culture of bullying and intimidation. The Review into the Welfare in Detention of Vulnerable Persons by Stephen Shaw, found in its January 2016 report that there should be a presumption against detention for persons with a diagnosis of PTSD, victims of rape and other sexual or gender--based violence and transsexual people, among others, and an absolute exclusion for pregnant women..$^{208}$

National legal frameworks frequently prove inadequate to provide protection against sexual abuse, particularly by not setting out adequate offences for abuse of power and various forms of gender-based violence. In the USA, the Prison Rape Elimination Act 2004, for example, does not directly apply to immigration detention, and it took until 2014 for the Department for Homeland Security to issue non-binding Standards to Prevent, Detect, and Respond to Sexual Abuse and Assault in Confinement Facilities. ${ }^{209}$ According to a Freedom of Information request, there were almost 200 allegations of sexual abuse in immigration detention from 2007 to 2011, most of which concerned Texas. ${ }^{210}$ In 2014, a complaint brought by the Mexican American Legal Defence and Educational Fund (MALDEF) raised "serious allegations of substantial ongoing sexual abuse in the Karnes Center [Texas] in violation of [US] law". ${ }^{211}$ The time it took, and the number of allegations and inquiries necessary to bring about change, illustrates the difficulties that reforms may face in countries such as the USA.

Torture is not confined to adult asylum seekers and migrants. As found by the Special Rapporteur on Torture, migrant children 'have been tied up or gagged, beaten with sticks, burned with cigarettes and given electric shocks', they also 'have suffered from severe anxiety and mental harm after having witnessed sexual abuse and violence against other detainees.'212

\section{Detention Conditions}

Minimum standards of detention applicable in the human rights field, apply equally to immigration detention. Nonetheless, in practice, immigration detention is subject to less regulation and oversight and consequently the standards can be extremely poor. This applies to the building structures which can be makeshift or ad hoc; overcrowding; significant security/controls (despite that the detainee population have committed no crime); poor hygiene, nutrition and healthcare. ${ }^{213}$ Health facilities within immigration detention centres are

\footnotetext{
${ }^{205}$ A review of entries in the country files of the Global Detention Project refers to allegation of ill-treatment and torture in countries such as Bulgaria, Hungary, Turkey, Ukraine, Morocco, Egypt, Malaysia, Japan and Mexico

206 Ruth Hopkins, 'South African prisoners sue G4S over torture claims', The Guardian, 13 February 2015

207 See Manus Island inquiry (n. 127)

208 Stephen Shaw, 'Review into the Welfare in Detention of Vulnerable Persons', Cm 9186, January 2016, pp 86-90

${ }^{209}$ DHS, Standards to Prevent, Detect, and Respond to Sexual Abuse and Assault in Confinement Facilities, 7 March 2014, 6 CFR Part 115

${ }^{210}$ American Civil Liberties Union, Sexual Abuse in Immigration Detention Facilities (19 October 2011)

${ }^{211}$ Marisa Bono, Complaints Regarding Sexual Abuse of Women in DHS Custody at Karnes Country Residential Center, MALDEF, 30 September 2014, http://www.maldef.org/assets/pdf/2014-09-30 Karnes PREA Letter Complaint.pdf

212 Special Rapporteur on Torture, Mission to Mexico, UN Doc. A/HRC/28/68/Add.3, 29 December 2014, para 60

213 Tarakhel v. Switzerland (Grand Chamber), Appl no 29217/12, 4 November 2014, para 47
} 
frequently not adequate to serve the multiple health needs of detainees, including to counter the risks of self-harm. In the UK, a woman miscarried her baby after inadequate treatment at Yarl's Wood immigration detention facility. Reportedly she was "spoken to" because she was "refusing to wait her turn". Eventually, four hours later she was seen by a visiting midwife who called an ambulance.214 In another case, Muhammad Shukat suffered a heart attack at Colnbrook Immigration Removal Centre and died in July 2011, with an inquest finding that neglect by the private security company running the detention facility, i.e. the failure to call an ambulance, had contributed to his death. ${ }^{215}$ Even when detainees do access healthcare, there are reports of them being restrained with handcuffs ${ }^{216}$ and denied privacy. ${ }^{217}$

Use of solitary confinement, inadequate nutrition and healthcare, failing to separate immigration detainees from criminal detainees and not providing adequate facilities for unaccompanied children, have all been raised in relation to the USA.218 The UN Special Rapporteur on the Human Rights of Migrants explains, in relation to Greece, that:

Irregular migrants are detained up to several months in various establishments, such as police stations, border guard stations and coast guard facilities, which are clearly not suitable for long-term detention. There are also some dedicated migration detention centres, some of which are converted military camps or police academies. As common standards are not applied, the detention conditions and the safeguards available vary significantly in the different establishments and locations. The Special Rapporteur visited 11 detention facilities in Greece. In general, detention conditions at all [sic] were inappropriate. Migrants were locked in their cells for most of the day with no activities to keep them occupied. Several of the detention centres did not have fenced-in outdoor areas, thus police officers were reluctant to letting the migrants go outside at all, as they risk disciplinary action if a migrant escapes. The conditions at Venna detention centre were particularly poor, and the Special Rapporteur was pleased to hear that this centre closed down shortly after his visit.

In some of the detention facilities, the migrants had limited access to toilets; some facilities had no artificial lighting so that during the winter, migrants were in the dark from early afternoon. Most of the detention facilities visited lacked heating and hot water and the detainees complained about insufficient amounts and poor quality of food, lack of soap and other hygiene products, as well as insufficient clothing, shoes and blankets. ${ }^{219}$

\section{Complaints concerning immigration detention}

It is next to impossible for individuals to challenge their placement in immigration detention, and even more so, their treatment inside detention. In practice, the systems put in place fuel the abuses. Some practices constituting or resulting in ill-treatment, such as potentially indefinite detention, may be understood to be lawful by the state in question. This can place a heavy onus

\footnotetext{
214 Jackie Long, 'Headbutt the bitch, Serco guard, Yarl's Wood, a UK immigration detention centre', OpenDemocracy, 2 March 2015 215 'Detention centre failures contributed to death of asylum seeker, inquest finds', The Guardian, 25 May 2012

216 See case brought against Serco (claimant restrained in ratchet handcuffs or closet chains on four occasions when he attended hospital for treatment, FGP v. Serco [2012] EWHC 1804

${ }^{217}$ HM Chief Inspector of Prisons, 'Report on an unannounced inspection of Harmondsworth Immigration Removal Centre' (5-16 August 2013), 5

218 The Advocates for Human Rights \& Detention Watch Network, United States of America: Violations of Article 3 and 16 Rights of Refugees, Asylum Seekers and Non-Citizens, 53 rd session of the United Nations Committee against Torture, 3-28 November 2014, UN Doc CAT/C/USA/CO/3-5, 19 December 2014, para.19

${ }^{219}$ Report by the Special Rapporteur on the human rights of migrants, François Crépeau, Addendum: Mission to Greece, UN Doc A/HRC/23/46/Add.4, 17 April 2013, paras 48, 49
} 
on asylum seekers and migrants to show in a given case that the system as it operates and impacts them personally, is unlawful. This is evident in the cases of F.K.G. et al v. Australia and M.M.M. v. Australia, in which the UN Human Rights Committee found that "The State party has not shown that its courts have the authority to make individualized rulings on the justification for each author's detention during the lengthy proceedings involved.'220

In some countries, there is no prompt or regular review of the legality of detention and the right to habeas corpus is often curtailed, particularly where detention is mandatory. ${ }^{221}$ Courts have also failed to address the individual circumstances of asylum seekers and migrants, sanctioning detention in a routine fashion. ${ }^{222}$ Even where it is in principle available, detainees often lack legal awareness and access to legal advice which would enable them to initiate proceedings. ${ }^{223}$

Complaints procedures in place are often inadequate or complex and confusing. In one case concerning a sexual violence allegation, "Sana", a 29 year-old Pakistani woman, who was detained at Yarl's Wood IRC (managed by Serco Group plc), alleged that she had been sexually assaulted on three separate occasions between November 2010 and January 2011 by a healthcare professional employed by Serco. ${ }^{224}$ Her complaint was initially dealt with by Serco, which failed to refer the matter for independent investigation as required. The UK Border Agency Professional Standards Unit, which does not constitute an independent body, undertook another investigation into Sana's case. After her case was eventually referred to Bedfordshire Police, the police undertook a "brief investigation" and reached a "definitive conclusion" to dismiss her allegations without having (i) considered all three of her separate allegations; (ii) interviewed the Serco officer who took her complaint at the outset; or (iii) sent an officer familiar with handling sexual assault cases (contrary to the police's own "Policy for the Investigation of Rape and Serious Sexual Assaults"). The Prisons and Probation Ombudsman subsequently found it difficult to understand "how the police found it possible to reach such a definitive conclusion after such a brief investigation" which appears to have been completed "in a matter of hours." 225

The challenges that have been brought concerning the arbitrariness of detention have been few and piece-meal. In the UK, the Government from 2011 to 2014 'paid nearly $£ 15$ million in compensation following claims for unlawful detention' in the immigration context.226 In several Australian cases, significant amounts of compensation were awarded for wrongful imprisonment or arbitrary detention.227 The Australian Human Rights Commission recommended payment of $\$ 450,000$ in a case of prolonged arbitrary detention of a Turkish national with mental health issues who awaited deportation and a written apology. ${ }^{228}$ Abdul Amir Hamidi, an Iranian asylum seeker, who was repeatedly and racially vilified during the four years spent in immigration detention from 2000-2004, sued Australia for failing in its duty of care. The Australian Government eventually settled the case for an undisclosed amount and reportedly sued the private contractors operating the detention centres at the time, Global

\footnotetext{
${ }^{220}$ M.M.M. et al. v. Australia, para. 8.3. See also F.K.A.G. v. Australia, paras. 8.3.-8.4

${ }^{221}$ Committee against Torture, Concluding observations on the combined fourth and fifth periodic reports of Australia, UN Doc. CAT/C/AUS/CO/4-5, 23 December 2014, para.16

222 UNHCR, Hungary as a country of asylum: Observations on the situation of asylum seekers and refugees, April 2012, para. 46

223 Submission from Bail for Immigration Detainees, 'Review into the welfare in detention of vulnerable persons', May 2015

${ }^{224}$ REDRESS, Submission to the All-Party Parliamentary Group on Refugees and the All-Party Parliamentary Group on Migration,

Inquiry into the Use of Immigration Detention, October 2014, para. 14

225 Ibid, para. 19

${ }^{226}$ A Joint Inquiry by the All Party Parliamentary Group on Refugees \& the All Party Parliamentary Group on Migration, Report of the Inquiry into the Use of Immigration Detention in the UK (March 2015)

${ }^{227}$ In Spautz v Butterworth \& Anor (1996) 41 NSWLR 1 (Clarke JA) 106, a case of wrongful imprisonment resulting in the plaintiff being incarcerated for 56 days, he was awarded \$75,000 in damages. In El Masri and Al Jenabi President Branson recommended for the Commonwealth to pay the complainant $\$ 90,000$ and $\$ 450,000$ as compensation for the 90 days and 16 months they were arbitrarily detained, respectively, in immigration detention. Al Masri v Minister for Immigration, Multicultural and Indigenous Affairs [2002] FCA 1009 (15 August 2002) Al Jenabi v Commonwealth of Australia (Department of Immigration and Citizenship) [2011] AusHRC 45

${ }^{228}$ Ince v. Commonwealth of Australia, [2013] AusHRC 62, para. 128
} 
Solutions Limited and Australasian Correctional Services, 'for failing to protect it against lawsuits lodged by people kept in [immigration] detention facilities.'229

The failure of procedures to effectively address complaints is reflected in the prevalence of selfharm and riots in immigration detention centres. While these practices can be attributed to a number of factors, statements by asylum seekers and migrants alleging torture and other illtreatment indicate that ineffective complaints procedures have been one of the causes of their frustration. Australia amended its Border Forces Act in 2015, prohibiting health professionals who provide medical services in immigration detention settings from speaking out publicly about anything they witnessed in the course of their work. ${ }^{230}$ Failure to do so carries a punishment of up to two years imprisonment. In addition, an amendment under consideration in mid-2015 considered vesting officials with immunity for anything done in good faith. ${ }^{231}$ Such a provision, which has served as a means to enshrine impunity for torture in many of the repressive countries individuals seek refuge from, is clearly incompatible with a state's obligations under international law unless it excludes serious human rights violations such as torture from its scope of application. ${ }^{232}$

Torture and ill-treatment cases concerning refugees and migrants in detention have been exceedingly difficult to pursue. This is particularly so where they remain in detention and face the prospect of imminent removal or deportation. But it is also next to impossible for victims to pursue cases once they have been removed from the jurisdiction. Despite the challenges, in several cases claims have been pursued through national human rights bodies and before domestic courts, as well as through regional and international courts and treaty bodies where domestic remedies failed. Some individual cases have led to prosecutions, such as that of Edwin Rodriguez, a guard in a prison run by Management \& Training Corporation (MTC), who was convicted for rape and sentenced to 14 months imprisonment in the USA though he was only suspended eight months after a complaint had been lodged. ${ }^{233}$ In Indonesia, ten detention centre employees were sentence to 10 months imprisonment for assault in relation to the beating to death of one Afghan detainee and the beating of three other detainees. Notwithstanding concerns over ill-treatment of detainees, the case did not result in any review or establishment of an effective complaints procedure. ${ }^{234}$ In the case of Velez Loor, which concerned a migrant who had been arbitrarily detained in Panama and subjected to torture, the Inter-American Court awarded $\$ 27,500$ compensation, ordered rehabilitation measures, an investigation into the alleged acts of torture and various guarantees of non-repetition. ${ }^{235}$

Detainees have also successfully pursued individual and class action cases against private contractors in the USA. Jesus Manuel Galindo, a Mexican national detained for illegally crossing the border at Reeves County Direction Centre run by Geo Group, died from an epileptic attack after being placed in solitary confinement as punishment for allegedly complaining about his medical condition. The lawsuit brought by his family was settled for an undisclosed amount.236 In the case of Brown v. Esmor Correctional Services, a number of former immigrant detainees alleged they had been "tortured, beaten, harassed and otherwise mistreated by Esmor guards

\footnotetext{
229 'Govt suing detention operators' Sydney Morning Herald, 10 October 2011

230 Sarah Whyte, 'Doctors and teachers gagged under new immigration laws', Sydney Morning Herald, 4 June 2015

${ }^{231}$ Migration Amendment (Maintaining the Good Order of Immigration Detention Facilities) Bill 2015

232 African Commission on Human and Peoples' Rights, Monim Elgak, Osman Hummeida and Amir Suliman (represented by FIDH and OMCT) v Sudan (2014)

233 Catherine Rentz, 'Detained and Abused: Will the federal government provide illegal immigrants the same protections as prisoners from sexual abuse?' 2 February 2012, www.justdetention.org/en/idinews/2012/02 02 12.aspx, Prison Legal News, Stateby-State Prisoner Rape and Sexual Abuse Round-Up, 15 April 2012, www.prisonlegalnews.org/news/2012/apr/15/state-by-stateprisoner-rape-and-sexual-abuse-round-up/

${ }^{234}$ Human Rights Watch, Barely surviving: Detention, abuse and neglect of migrant children in Indonesia, 2013, 33-35

235 Case of Vélez Loor v. Panama (Preliminary Objections, Merits, Reparations and Costs), 23 November 2010, paras. 255-314

${ }^{236}$ Forrest Wilder, 'The Percos Insurrection: how a private prison pushed immigrant inmates to the brink', The Texas Observer, 8 October 2009 and Fusion, Shadow Prisons: A private and profitable corner of the federal prison system thrives after a long-ignored offense is prosecuted, 4 February 2015, http://interactive.fusion.net/shadow-prisons/
} 
and that they were subjected to abysmal living conditions including inadequate sanitation, exercise and medical treatment”. ${ }^{237}$ They were awarded US $\$ 2.5$ million by the private company that ran the facility in Elizabeth, New Jersey.

Private actors exercise elements of governmental authority where they are entrusted with security functions in detention settings, particularly where they are empowered to use force. ${ }^{238}$ In Cabal and Bertran v. Australia, the UN Human Rights Committee underscored that a state 'is not relieved of its obligations under the Covenant when some of its functions are delegated to other autonomous organs. ${ }^{239}$ Similarly, the UN Committee against Torture has determined that, 'where detention centres are privately owned or run, ... personnel are acting in an official capacity on account of their responsibility for carrying out the State function without derogation of the obligation of State officials to monitor and take all effective measures to prevent torture and ill-treatment.'240

The rulings, though only benefiting a limited number of persons, set important precedents. They show that both governments and private contractors can be liable, and that violations can result in significant costs for those responsible. However, this may still not result in broader systemic changes if damages are viewed, and absorbed as an inherent cost of "doing business".

\section{IV.4.3 Removals}

Rejected asylum seekers are persons who are determined (whether appropriately or not) not to be in need of international protection and they are regularly subjected to removals. The rejection of an asylum claim and removal of a person who has a well-founded fear of persecution and/or who faces a real risk of torture or ill-treatment on return is contrary to the international prohibition of refoulement. Under the safe third country principle, asylum seekers can be returned to a country through which they travelled if it is understood to be a 'safe-third country'. If that country is not 'safe', and/or the person faces a risk of onward refoulement from that country, this breaches the obligations of the country carrying out the initial removal.

Removal and deportation powers form an important component of deterrence policies, signalling to any failed asylum seekers or other "irregular" migrant that they will not be able to remain in the destination country. Several states have therefore sought to expedite these processes. Forcible and fast-tracked removals and deportations have led to a number of problems ranging from inadequate consideration of asylum claims resulting in denials of asylum and refoulement, and the use of excessive force including ill-treatment sometimes amounting to torture and resulting in injuries and death in some cases. The Council of Europe's Committee for the Prevention of Torture has indicated in relation to removals by air in particular, that 'such operations entail a manifest risk of inhuman and degrading treatment (during preparations for the deportation, during the actual flight or when the deportation is aborted).'241

The UK case of Jimmy Mubenga illustrates some of the multiple problems with the implementation of forced removals. Mr. Mubenga, an Angolan national, had unsuccessfully

\footnotetext{
237 Samson Brown et al v. Esmor Correctional Services et al, Civ. No. 98-1282 (DRD) (2005)

${ }^{238} \mathrm{R}$ (on the application of) $v$ SSHD [2011] EWHC 2120 (Admin), para. 222; FGP v Serco Plc \& Anor [2012] EWHC 1804 (Admin) (05 July 2012), para. 2, and Prison Legal News, 'Texas Courts holds CCA is a governmental body in PLN public records suit', 1 January 2014, www.prisonlegalnews.org/news/2014/apr/15/texas-court-holds-cca-is-a-governmental-body-for-purposes-of-publicrecords-law, citing Prison Legal News v. CCA, Travis County District Court, 353 ${ }^{\text {rd }}$ Judicial District, Cause No. D-1-GN-13-0014445

${ }^{239}$ Cabal and Bertran v. Australia, UN Doc CCPR/C/78/D/1020/2001, 7 August 2003, para. 7.2

240 See Committee against Torture, General Comment No. 2, para. 17

${ }^{241}$ Committee for the Prevention of Torture, Report to the Government of the United Kingdom on the visit to the United Kingdom carried out by the European Committee for the Prevention of Torture and Inhuman or Degrading Treatment or Punishment (CPT) from 22 to 24 October 2012, para. 9
} 
applied for asylum in the UK in the mid-1990s. While his and his wife's application for indefinite leave to remain was pending, he was, in 2006, sentenced to 2 years imprisonment for assault occasioning actual bodily harm, which resulted in a decision to deport him to Angola. On 12 October 2010, three Detention and Custody Officers employed by the private company G4S escorted Mr. Mubenga to Heathrow Airport to board a plane to Angola. While on board the flight, a struggle ensued and Mr. Mubenga was held in a position in which his breathing was impeded, which led to his unlawful killing. ${ }^{242}$

The coroner found a number of serious shortcomings. These included the fact that (i) G4S staff was allowed to carry out removals and use force without the required statutory accreditation; (ii) the system of paying contractors by results, i.e. successful removals, 'carries with it the risk that removals will go ahead in circumstances where otherwise they might be aborted. Having a financial interest in getting the job done gives rise to real concerns that inappropriate methods might be used to that end';243 (iii) there was evidence of 'a more pervasive racism within G4S'; 244 (iv) there were multiple concerns regarding the use of force, including inadequate training, the use of "control and restraint" on an aircraft, bad practice (pushing a deportee's head downwards), handcuffing to the rear and restraint/positional asphyxia; and (v) the failure to administer first aid. The report concluded by emphasising that ' $[\mathrm{u}]$ ltimately, the Home Office carries responsibility for immigration law and policy and it is the Home Office that has ultimate responsibility for ensuring that any removals are carried out safely.'245 The Crown Prosecution Service, following the Inquest report, reversed its decision not to prosecute the three G4S staff involved for manslaughter. The subsequent trial ended in a jury acquittal in December 2014; the jury had not been informed of the inquest verdict of unlawful killing and the racist materials found on the accused. ${ }^{246} \mathrm{An}$ appeal was later dismissed. ${ }^{247}$

While the Mubenga case took place within a - flawed - legal framework, other states have resorted to particularly crude methods of expulsions that do not even retain the appearance of being in compliance with any law. In a case that eventually came before the UN Committee Against Torture and resulted in findings of a violation of article 16 of the Convention Against Torture, Morocco was found responsible for having abandoned around '40 migrants some of whom were severely injured, in the border area separating Morocco and Mauritania without adequate equipment and with minimal supplies of food and water, and forc[ing] them to walk some 50 kilometres through an area containing anti-personnel mines.' 248

In response to growing concerns about the excessive force in a number of countries, a number of standard setting bodies have elaborated guidelines or directives to limit the use of force in removals and deportations. For instance, Article 8 (4) of the EU returns directive provides that 'coercive measures shall be proportionate and not exceed reasonable force. They shall be implemented as provided for in national legislation in accordance with fundamental rights and with due respect for the dignity and physical integrity of the third-country national concerned.' The Council of Europe has similarly recommended that states introduce 'specific regulations which strictly forbid the following practices: [...] the arbitrary or disproportionate use of force.'249 Similar principles are echoed in the EC Common Guidelines on security provisions for

\footnotetext{
${ }^{242}$ Report by the Assistant Deputy Coroner Karon Monaghan QC under the Coroner's Rules 1984, Rule 43, Inquest into the Death of Jimmy Kelenda Mubenga, 31 July 2013, para.18, setting out the Jury's Verdict.

243 Ibid, para. 38

244 Ibid, para. 43

245 Ibid, para. 82

${ }^{246}$ Robert Booth and Matthew Taylor, 'Jimmy Mubenga's widow shocked as security guards cleared of manslaughter', The Guardian, 16 December 2014

247 The Queen (on the application of F1) v. Secretary of State for the Home Department [2014] EWCA Civ 1272

${ }^{248}$ Barry v. Morocco, UN Doc CAT/C/52/D/372/2009, 19 May 2014, para.7.2 (violation of article 16)

${ }^{249}$ Council of Europe Recommendation 1547 (2002), Expulsion procedures in conformity with human rights and enforced with respect for safety and dignity; Council of Europe, Committee of Ministers, Twenty Guidelines on Forced Return, September 2005
} 
joint removals by air, ${ }^{250}$ as well as in recommendations made by European Committee for the Prevention of Torture. 251

Eurodac regulations requiring fingerprinting of persons arriving within the EU, ${ }^{252}$ when considered alongside the Dublin regulation has resulted in ill-treatment. Several reports and a study based on interviews with asylum seekers ${ }^{253}$ have highlighted the excessive use of force by personnel seeking to take fingerprints which may amount to ill-treatment. Male asylum seekers reported they were beaten in front of their child (in Italy), had to undress and were lashed (in Bulgaria), were beaten with electroshock devices (in Hungary), and had to lie naked on the floor while being hit and kicked (in Slovakia) before their fingerprints were taken. ${ }^{254}$ In Bulgaria, asylum seekers who refused to be fingerprinted reported that they were threatened with further detention and subjected to ill-treatment in several cases; asylum seekers were warned not to complain about their treatment and threatened with various sanctions if they did.255 While the regulations make clear that states are bound to apply them in accordance with their relevant human rights obligations, the regulations lack specific guidance on the use of force. Interviews with those alleging ill-treatment suggest that the individuals were deeply traumatised by their treatment and do not appear to have had access to effective complaints procedures and remedies.

Some individuals have also been subjected to detention and torture on arrival in the countries from which they fled. In a number of cases, there is evidence that persons that have been refouled have subsequently experienced torture and other forms of cruel, inhuman or degrading treatment or punishment. The later ill-treatment of deported/returned persons is not a condition precedent for determining whether a person was refouled (the test as the Committee Against Torture has made clear concerns the risk of such treatment; the fact that the treatment ultimately occurred is not necessary as such). Nevertheless, there are documented cases of torture and ill-treatment of returnees, when the risk of that treatment was sufficiently clear to the returning authorities. For instance, there are numerous reports of forced returnees to Sri Lanka being subjected to torture, including rape by security services. ${ }^{256}$ There are reports that Sudanese forcibly returned from Jordan were detained and some tortured. A young Sudanese activist who was kept incommunicado for 10 days said on his release, 'They asked us many questions,' 'I cannot describe what they did to make us answer the questions.'257

Complaints procedures concerning removals, the removal process and treatment suffered postreturn as well as remedies for such harms have been ineffective, largely because those affected are outside of the jurisdiction where the complaint needs to be filed and often in precarious

\footnotetext{
${ }^{250}$ Common Guidelines on security provisions for joint removals by air annexed to Decision 2004/573/EC. See also, Guideline 18: Use of Escorts: para 2 International Air Transport Association \& Control Authorities Working Group, 'Guidelines on Deportation and Escort,' in ECAC Policy Statement in the Field of Civil Aviation Facilitation, ECAC.CEAC Doc No. 30, 2003, Part 1, Annex D, para. 8, Use of Restraints in Flight: ' 8.2 Escorts should be trained in the safe use of, and, subject to government regulation and the transporting operator's policy, have access to appropriate restraint devices when accompanying a deportee.'

${ }^{251}$ European Committee for the Prevention of Torture, CPT Standards, CPT/Inf/E (2002) 1 - Rev. 2013, para. 34

${ }^{252}$ Council Regulation No 2725/2000 of 11 December 2000 concerning the establishment of 'Eurodac' for the comparison of

fingerprints for the effective application of the Dublin Convention, and, as from 20 July 2015, Regulation (EU) No 603/2013, on the establishment of 'Eurodac' for the comparison of fingerprints for the effective application of Regulation (EU) No 604/2013 establishing the criteria and mechanisms for determining the Member State responsible for examining an application for international protection lodged in one of the Member States by a third-country national or a stateless person and on requests for the comparison with Eurodac data by Member States' law enforcement authorities and Euro pol for law enforcement purposes, and amending Regulation (EU) No 1077/2011 establishing a European Agency for the operational management of large-scale IT systems in the area of freedom, security and justice (recast)

${ }^{253}$ Sven Veigel and Mechthild Wenk-Ansohn, 'Gewalt mit Methode? Das “Dublinverfahren” und Menschenrechtsverletzungen an den EU-Außengrenzen', Asylmagazin 6/2015, 187-193

${ }^{254}$ Ibid, 190-191

255 Pro Asyl, Erniedrigt, misshandelt, schutzlos: Flüchtlinge in Bulgarien (April 2015), http://www.proasyl.de/fileadmin/fmdam/NEWS/2015/150415 Bulgarienbericht.pdf

${ }^{256}$ See, Human Rights Law Centre, 'Torture, Rape and Ill-Treatment Suffered by Sri Lankans who Return Home', September 2014, http://hrlc.org.au/wp-content/uploads/2014/09/HRLC BackgroundBrief SriLankan returnees Sep2014.pdf; Human Rights Watch, “"We Will Teach You a Lesson” Sexual Violence against Tamils by Sri Lankan Security Forces', February 2013

${ }^{257}$ Bethan Staton, 'Sudanese refugees forcibly deported from Jordan fear arrest and torture', The Guardian, 19 January 2016.
} 
situations with little access to legal or other support. There should be a remedy for an unlawful removal which constitutes refoulement regardless of whether a person was ultimately tortured or ill-treated, however there is little evidence of such cases in practice. International monitoring bodies such as the UN Committee Against Torture have encouraged states to afford reparation, including compensation and rehabilitation to individuals who have been refouled, 258 and to carry out post-return monitoring, ${ }^{259}$ and to take steps to ensure the individual is not subjected to torture. ${ }^{260}$ Equally, and despite the recognition that restitution - to return the person to the status quo ante which preceded the violation - is the ultimate goal of reparation, there have been very few instances in which courts have ordered individuals who have been wrongfully refouled to be returned to the jurisdiction. Once out of the jurisdiction, it may be difficult for the returning state to have access to the individuals, particularly if they have been detained on arrival.

${ }^{258}$ Boily v. Canada, Comm. No. 327/2012, 13 January 2012, para. 15

259 Inass Abichou v. Germany, Comm. No. 430/2010, 16 July 2013, para. 13

${ }^{260}$ Alexey Kalinichenko v. Morocco, Comm. No. 428/2010, 18 January 2012, para. 17 


\section{Global burden sharing}

The preamble to the 1951 Convention recognises that: '[t]he grant of asylum may place unduly heavy burdens on certain countries, and that a satisfactory solution of a problem of which the United Nations has recognized the international scope and nature cannot therefore be achieved without international co-operation.' International cooperation to solve transnational and global problems is a common feature and primordial goal of the web of regional and international institutions which have proliferated over the last century. But has it worked? And specifically, has it worked to address the plight of refugees and the mass movements of people?

International burden-sharing can help to fairly distribute refugee populations more evenly and not place the responsibility to host refugees simply on the country where they happen to arrive. But only ten countries host nearly 60 percent of the world's refugees, and 86 percent of the world's refugees are in developing regions of the world. The most developed countries have by and large shirked their responsibility to take their share of refugees, focusing their interventions on financial and material support. The UNHCR Executive Committee Conclusion on International Cooperation and Burden and Responsibility Sharing in Mass Influx Situations, agreed in 2004 aimed to encourage more effective and predictable responses to mass influx situations and to improve responsibility-sharing arrangements to share the burdens of first asylum countries. The 19 September 2016 draft Summit Declaration affirms states' commitment to burden sharing: 'We underline the centrality of international cooperation to the refugee protection regime. We recognize the burdens that large movements of refugees place on national resources, especially in the case of developing countries. To address the needs of refugees and receiving States, we commit to a more equitable sharing of the burden and responsibility for hosting and supporting the world's refugees, while taking account of existing contributions and the differing capacities and resources among States.' ${ }^{261}$

Burden sharing has become the lingua franca in diplomatic negotiations on refugee and migration solutions. But in the world of real politik led by national interests, global burden sharing has been characterised on the one hand by the growing pleas from those countries that host the majority of refugees to other countries to take up the challenge of resettlement, and on the other hand, by developed, mainly western states seeking to broker arrangements with and incentivising neighbouring states to better control their borders and prevent refugees from reaching Western borders. What chance is there for a more equitable reframing? Unlike the Universal Declaration of Human Rights which incorporates in Article 14 a right to seek asylum, the Refugee Convention does not recognise any right of entry for the purposes of seeking asylum other than through the back door of the corollary principle of non-refoulement. Amnesty International has gone so far as to term the G20's burden sharing call as 'hypocritical'.262

Burden sharing has been a common feature in Europe but is principally about restricting access. An example in point is the EU-Turkey Agreement of 18 March 2016 which calls on refugees to be returned from Greece to Turkey, despite the huge refugee burden Turkey already sustains and the violence and human rights violations taking place in that country. Another example is the 'Khartoum process', an agreement between the EU and the Horn of Africa migration route states of Djibouti, Egypt, Eritrea, Ethiopia, Kenya, Somalia, South Sudan and Tunisia, agreed on the guise of thwarting trafficking and smuggling rings but clearly also aimed at curbing migration to Europe. The now almost collapsed Dublin system, ${ }^{263}$ another case in point, creates

\footnotetext{
261 Outcome Document for 19 September 2016 High-Level Meeting to Address Large Movements of Refugees and Migrants, Draft for Adoption, 29 July 2016, para 4.5

${ }^{262}$ Amnesty International, 'G20 "burden-sharing" call on refugee crisis hypocritical', 5 September 2016

${ }^{263}$ ECtHR, M.S.S. $v$ Belgium and Greece (Grand Chamber), Appl no 30696/09, 21 January 2011; Joined Cases C-411/10 and C-493/10 NS and Others [2011] ECR I-0000
} 
a presumption that all EU Member States are equally safe countries for refugees and obliges refugees to apply for asylum in the first country of entry in the EU, which has placed a disproportionate responsibility on Italy, Greece and other countries at the EU's external borders. ${ }^{264}$ Reforms to the system have been thwarted by other EU countries that benefit from the unequal burden sharing the system produces.

Burden sharing has also been a common feature in Asia. The Comprehensive Plan of Action for Indochinese Refugees (CPA) ${ }^{265}$ provided temporary refuge for asylum-seekers from Viet Nam and the Lao People's Democratic Republic, reduced clandestine departures, expanded legal departure possibilities and introduced region-wide refugee status determination procedures which helped stem the flow of asylum-seekers. It also facilitated the recognition and subsequent resettlement of Vietnamese and Lao refugees. But the more recent Bali process - the Conference on People Smuggling, Trafficking in Persons and Related Transnational Crime, ${ }^{266}$ a forum for policy dialogue, information sharing and practical cooperation, has not led to any real burdensharing on the reception and integration of refugees. Australia too, has been ensconced in the negotiation of a series of bilateral treaties and protocols with neighbouring countries on the purported basis of burden-sharing, but principally to stem the flow of refugees to its borders by externalising its obligations.

The problem with burden sharing, whether on the regional or international level, is that it only works if all states play their part. The moment some states refuse, this increases the burden on others and reduces the incentives for all. Burden sharing requires a high moral compass, it demands an international view which trumps national interests, and therein lies the challenge.

\footnotetext{
${ }^{264}$ As recast: Council Regulation (EC) 604/2013 on establishing the criteria and mechanisms for determining the Member State responsible for examining an asylum application lodged in one of the Member States by a third-country national or a stateless person (recast Dublin Regulation) [2014] 0J L180/31

265 Adopted at the International Conference on Indo-Chinese Refugees, Geneva, 13-14 June 1989

${ }^{266}$ http://www.baliprocess.net/. See, Bali Declaration on People Smuggling, Trafficking in Persons, and Related Transnational

Crime, Sixth Ministerial Conference of the Bali Process on People Smuggling, Trafficking in Persons and Related Transnational Crime, 23 March 2016
} 


\section{Conclusions \& Recommendations}

This Report demonstrates that refugees and other migrants experience torture and illtreatment at all stages of their "journey". The laws and policies put in place by states to respond to the influx are mainly premised on deterrence as opposed to humanitarianism or respect for legal principles. By thwarting safer and legal modes of entry such as access to the destination country for the purpose of applying for asylum, these responses increase the resort to traffickers and smugglers and in the process heighten the risks that those seeking entry will be subjected to torture and related abuse.

We call on States to adopt a more humane approach to refugees and migrants, and to stop pandering to the most xenophobic voices amongst their national constituencies. Racism and hate crimes should not form the basis of refugee and migration policies. There are other voices that should be listened to, and these are being mobilised, though perhaps not fast enough. States have a crucial role to play in changing the rhetoric towards recognition of the human dignity of each person seeking and requiring protection. With the benefit of hindsight, states should be minded to reflect more on why the Refugee Convention was adopted in the first place.

Burden sharing is a vital ingredient for responses to mass influxes however it can only work if states find ways to work collaboratively beyond what they perceive to be their own national interests and accept that a part of burden sharing is accepting resettlement. This requires a moral sea change, and a will to innovate. There are few great examples to draw upon; new solutions are needed and these must reflect the inalienable rights that each refugee and migrant possesses, including the right not to be refouled, including the right to be free from torture and other cruel, inhuman and degrading treatment or punishment. Rights are not and cannot be ignored in situations of mass influx; these situations are the precise moments when rights frameworks are most needed.

The Report demonstrates the need to take the prohibition of torture and ill-treatment seriously in the laws, policies and practice of dealing with refugees and other migrants. This requires that immigration control measures are not part of exceptional regimes but are subject to the same standards of protection that apply generally, including preventive measures, particularly adequate safeguards and oversight, effective accountability mechanisms and victims' rights to an effective remedy. States may no more torture a person at home, than abroad: 'As States bend the rules or hunt for the "gaps," attention must focus increasingly on those who are behind the policies and practices that impact on the security and well-being of others, as well as on those who implement them. This is not just a question of responsibility at the inter-State level, but concerns also that liability which attaches to individual agents of the State, to officials, to military commanders, to the members and crews of particular units or vessels.'267 States must be committed to sanction the refoulers, the torturers, the abusers and not only the smugglers and traffickers who make use of porous borders. It cannot be $\mathrm{OK}$ to leave the most vulnerable victims of unimaginable atrocities in urban 'jungles' in Calais, barely floating boats at sea or insecure refugee camps in parts of Africa, Asia and the Middle East. It cannot be OK for children to grow up in deplorable conditions in camps, without opportunities for a future. It is time to reset the moral compass.

Taking the prohibition of torture seriously also requires that states take responsibility and operate systems without outsourcing them to actors who are for various reasons not best

${ }^{267}$ Guy S. Goodwin-Gill, 'The Continuing Relevance of International Refugee Law in a Globalized World' (2015) 10 Intercultural Hum. Rts. L. Rev. 25, 37 
placed to provide the level of protection needed. A particular pressing area for reform is immigration detention. Such detention must be exceptional and alternatives provided. This would significantly reduce the risk of torture and ill-treatment. Finally, respect for the physical and mental integrity of asylum seekers cannot be divorced from the procedure of processing refugee claims. The perceived arbitrariness and lack of fairness of these procedures has caused great harm and contributed to resistance on the part of individuals concerned, which has in turn prompted the use of (at times excessive) force. Fair systems are therefore crucial to ensuring that refugees are recognised, and that no-one who has been tortured or ill-treated, or faces a risk of such treatment, will have to experience any treatment akin to this while looking for safety and protection. 


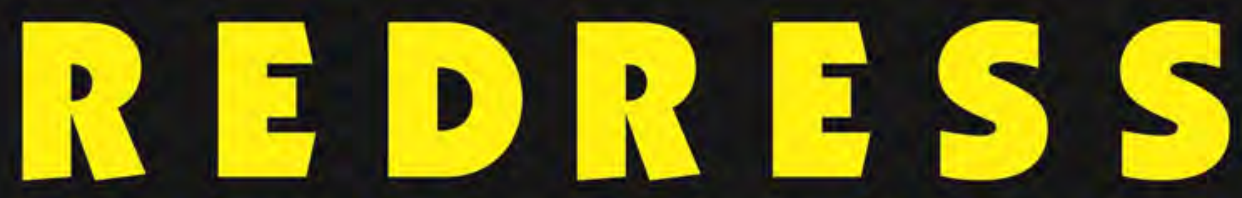

Ending Torture, Seeking Justice for Survivors

87 Vauxhall Walk, London, SE11 5HJ

United Kingdom

Tel: +44 (0)20 7793 1777; email: info@redress.org

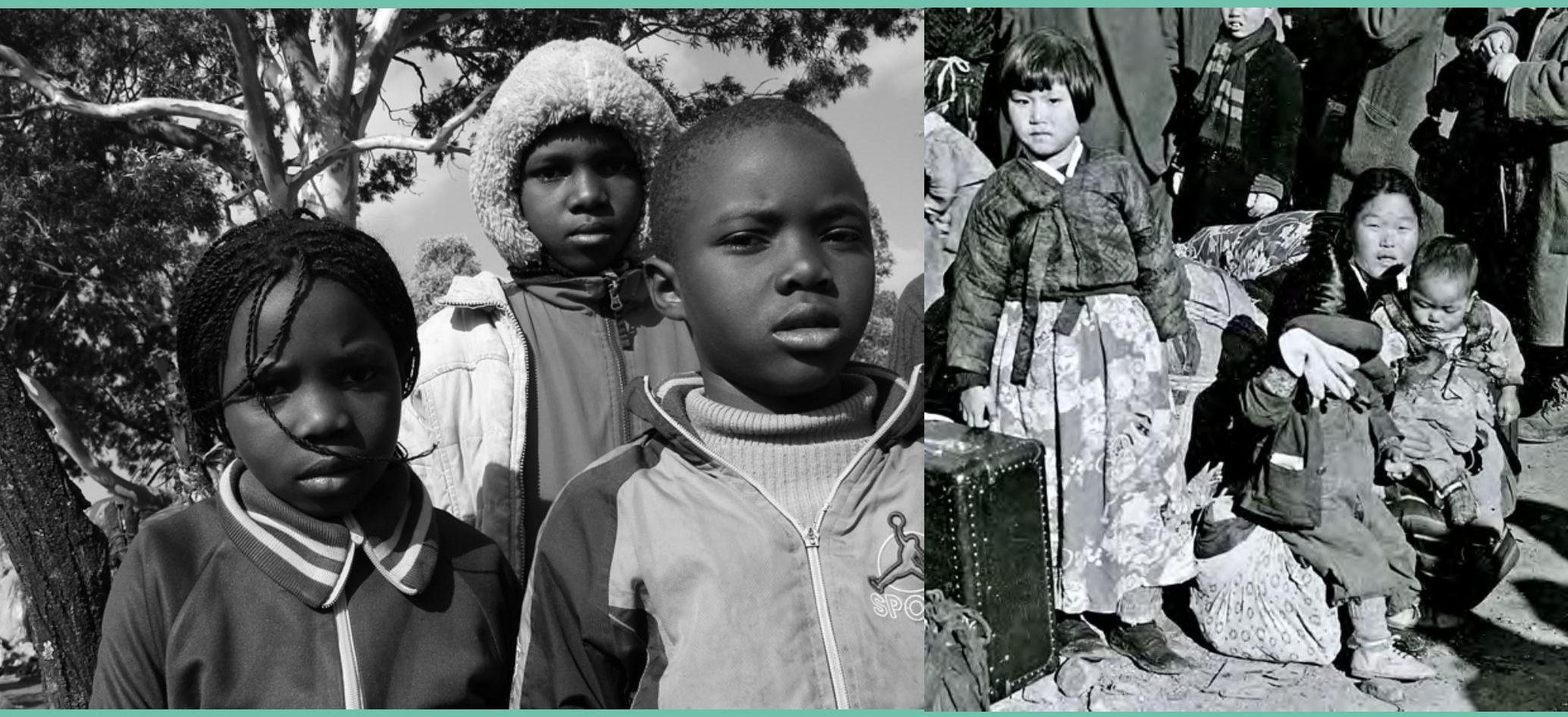

We are very grateful for the support of the European Instrument for Democracy and Human Rights

$$
\begin{aligned}
& \star^{\star \star} \star \star \\
& \star \quad \star \\
& \star \star \star \star^{\star}
\end{aligned}
$$

